\title{
Forecasting Macroeconomic Variables Using Data Dimension Reduction Methods: The Case of Korea
}

\author{
Hyun Hak Kim*
}

The views stated herein are those of the author and not necessarily those of the

Bank of Korea. When reporting or citing it, the author's name should always be stated explicitly.

* Economist, Macroeconomics Team, Economic Research Institute, The Bank of Korea, 55 Namdaenunno, Jung-gu, Seoul 100-794, Korea, khdouble@bok.or.kr

The author especially thanks Norman Swanson, Woon Gyu Choi, Hyun Jeong Kim, Ki-ho Kim, Youngjae Chang, and other seminar participants for their valuable comments. 


\section{Contents}

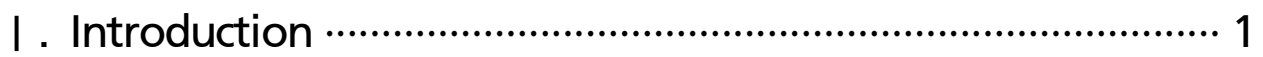

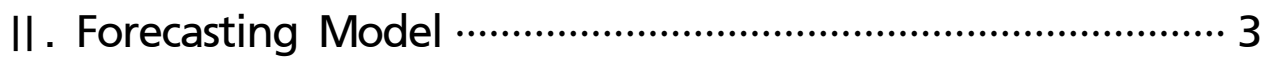

III. Sparse Principal Component Analysis ……………………... 7

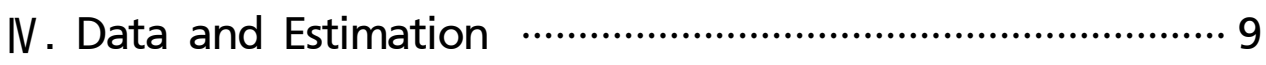

V. Comparison of Two Principal Components …………….... 12

VI. Experimental Results ……………………………............. 18

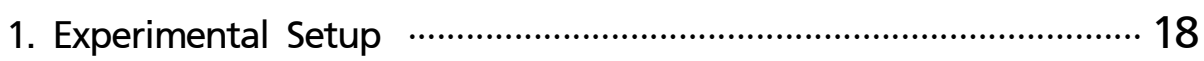

2. Results: Consumer Price Index ……………………....................... 19

3. Results: GDP growth rate …………………………………... 23

4. Results: Consumption …………………………………………. 24

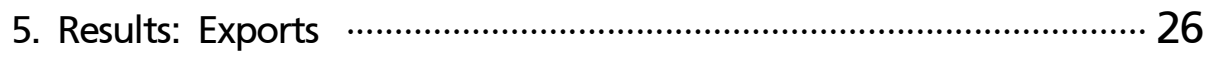

6. Results: Gross Capital Formation ……………………………..... 27

VII. Concluding Remarks ……................................................ 29

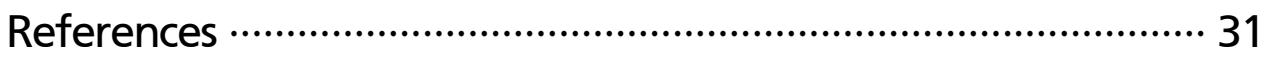

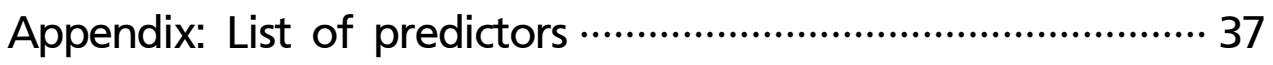




\section{Forecasting Macroeconomic Variables Using Data Dimension Reduction Methods: The Case of Korea}

This paper investigates the usefulness of the factor model, which extracts latent information from a large set of data, in forecasting Korean macroeconomic variables. In addition to the well-known principal component analysis (PCA), we apply sparse principal component analysis (SPCA) to build a parsimonious model, and combine the estimated factors with various shrinkage methods, following Stock and Watson (2012) and Kim and Swanson (2013a), to forecast CPI inflation, GDP growth, exports, consumption and gross capital formation (GCF) of Korea from 2003:01 to 2012:12. Our major findings are that, in predicting growth rates, various hybrid models outperform benchmark models including an autoregressive model, and that this result becomes clearer as the forecast horizons lengthens. Specifically, in forecasting for more volatile periods like the global financial crisis during 2008-09, various hybrid models predict the inflection point better than AR model does. The auxiliary finding is that the main ingredients of Korean macroeconomic variables as indicated by SPCA include interest rates, construction orders received, and employment variables. Surprisingly, the monetary aggregates or price variables are never found to contribute to the principal components in our experiment.

Keywords: Prediction, Sparse Principal Component Analysis, Bagging, Boosting, Bayesian Model Averaging, Ridge Regression, Least Angle Regression, Elastic Net And Non-Negative Garrote

JEL Classification: C32, C53, G17 


\section{Introduction}

As computation technologies are getting, remarkably, more powerful in recent decades, richer the quantity of financial and macroeconomic data becomes. Truly, there has been tremendous research, both in computation and theories, to keep pace with the enlarging amount of data, also called as 'big data'. In economics literature, one of the most widely applying field is the diffusion index methodology, also called factor model, which enable us to take a simpler and more sensible approach to extracting common component underneath dynamic evolution of a large number of variables. More specifically, many studies adopt the so-called 'dimension reduction' methods in the forecasting context, including Stock and Watson (2002), who used principal component analysis (PCA) in constructing factors. Such factors are "a few" latent variables which explain the variances in a large set of variables. To be more specific, let $X$ be a time-series predictor matrix of $N$ variables, and extract $r(<N)$ unobserved common factors $F$ from $X$. Using the common factors thus extracted with PCA, Stock and Watson (2002) forecasted US macroeconomic variables. PCA-based factor models have generated an extensive literature, including Armah and Swanson (2010, 2011), Artis et al. (2002), Bai and $\mathrm{Ng}$ (2002, 2006, 2009), Boivin and Ng (2005, 2006) and Stock and Watson (2005, 2006, 2012). Meanwhile, Kalman Filtering (KF) has also been used in constructing factors for forecasting: e.g. by Banerjee and Marcellino (2008), and Dufour and Stevanovic (2010), who suggest that KF works better than PCA under certain conditions.

There are also many empirical studies that predict individual country variables using the factor model described above. For examples from advanced countries, Angelini, Bańbura and Rünstler (2008) predicted the euro area's macroeconomic variables, Bessec (2012) did the same for French GDP, den Reijer (2005) for Dutch macroeconomic variables, Schumacher (2007) for German GDP, and Schneider and Spitzer (2004) for Austrian GDP.1) There have been numerous cases for

1) Other cases from the advanced economies include Kapetanios, Labhard and Price (2007) for macroeconomic variables in England, Godbout and Lombardi (2012) for Japanese macroeconomic variables, both Gosselin and Tkacz (2001) and Cheung and Demers (2007) for Canadian GDP and inflation, and 
emerging countries as well,2) but no research has yet forecast Korean macroeconomic variables using this kind of factor model although Lee (2004) applied PCA in forecasting the inflection point of the Korean economy's business cycle. ${ }^{3)}$

In spite of PCA's good forecasting performance, it is very hard to tell exactly what any individual factor implicates. To overcome this problem, we apply sparse principal component analysis (SPCA), which enables us to extract parsimonious factor loadings following Kim and Swanson (2013b). In SPCA a small number of variables are selected to construct "sparse" factors which help analyze the composition of such factors. However, these sparse factors are based on the covariance structure of a predictor set, and do not tell the relationships between the dependent variables and the explanatory ones. Stock and Watson (2012) use various shrinkage methods to pick appropriate factors among the principal components. In light of this, following Bai and $\mathrm{Ng}$ (2008, 2009), Stock and Watson (2012), and Kim and Swanson (2013a), we implement a forecasting model in which factors are selected using various shrinkage methods including bagging, boosting, Bayesian model averaging, simple model averaging, ridge regression, least angle regression, elastic net and non-negative garotte. Kim and Swanson (2013a) have shown in their empirical work that models based on these shrinkage methods have produced better predictions.

In this paper, we first estimate unobserved factors at the time $t, \widehat{F}_{t}$, using PCA and SPCA and then forecast a target variable $\widehat{Y}_{t}$, with these given factors using various shrinkage methods. This "hybrid" model works well and outperforms benchmark models such as AR model for US macroeconomic variables in Kim and Swanson (2013b). We follow their approach with Korean macroeconomic variables. To the best of our knowledge, no research has as of yet forecast Korean macro-

Matheson (2006) for macroeconomic variables in New Zealand.

2) Examples include Ajevskis and Davidsons (2008) for Latvian GDP, Cheng and Lin (2011) for Taiwanese macroeconomic variables, Chow and Choy (2008) for Singaporean's GDP, Gupta and Kabundi (2011) for South African macroeconomic variables, Ibarra-Ramirez (2010) for the Mexican inflation rate, Kunovac (2007) for Croatian inflation, Rogleva (2011) for Bulgarian GDP, and Stakènas (2012) for Lithuanian GDP.

3) As well as forecasting macroeconomic variables, research including Engle et al. (2012) and Marcucci (2008) have investigated high frequency financial variables, and shown empirically that models that consider factors facilitate better forecasting than the simple autoregressive model. 
economic variables using data dimension reduction methods. This paper empirically assesses the predictive accuracies of various linear models and diffusion index models combined with various shrinkage methods. This comparison allows us to provide new evidence on the usefulness of the factor model in Korea as well as on various related issues such as whether model averaging outperforms, as is usually found to be the case. The variables that we predict include a variety of macroeconomic variables useful for evaluating the state of the economy such as CPI inflation, GDP growth, consumption, exports and gross capital formation (GCF).

The rest of the paper is organized as follows. The next section introduces the forecasting framework, along with a briefly describing the various shrinkage models. Section 3 explains how the sparse principal component analysis is implemented. Section 4 discusses the data and means of determining the number of factors, and Section 5 presents interpretations of the sparse principal components. The empirical results are then provided in Section 6, and concluding remarks are given in Section 7.

\section{Forecasting Model}

Stock and Watson (2002) suggest the following model, in which factors are added into the ordinary autoregressive model;

$$
Y_{t+h}=W_{t} \beta_{W}+F_{t} \beta_{F}+\epsilon_{t+h},
$$

where $Y_{t+h}$ is the $h$-step ahead forecast value, $W_{t}$ are the constants and the lagged values of the dependent variable, $F_{t}$ is a vector of factors, and $\epsilon_{t}$ is the error term. This model is called the factor augmented autoregression (FAAR) or simply 'factor model' in the existing research.

The estimation of (1) consists of two steps. The first step extracts factors, $F_{t}$ from the estimation of the following equation: 


$$
X=F \Lambda^{\prime}+e,
$$

where $X$ is a $T \times N$ matrix, $F$ is a $T \times r$ matrix, and $\Lambda$ is an $N \times r$ matrix, also called a loading vector. A principal component of PCA is a linear combination of all variables. More specifically, PCA considers the variances within a predictor set, $X$, in the sense that a principal component is constructed as a linear combination of all explanatory variables with non-zero coefficients like the following,

$$
P_{i}=a_{1 i} X_{1}+a_{2 i} X_{2}+\ldots+a_{N i} X_{N}
$$

where $P_{i}$ is the $i$-th principal component, and all coefficients, $a_{1 i}, \ldots, a_{N i}$, also called loadings, are non-zero. Even though various literature show that PCA works very well in forecasting, it is difficult to tell what each factor implies. SPCA, in contrast, produces sparse loadings. More specifically, some of the loadings in equation (3) are not non-zero in SPCA. This means that limited subset of the variables is used in constructing components, enabling us to interpret what each component indicates. And this SPCA is applied to construct factors and its loadings of (2).

Once factor $F_{t}$ is estimated through PCA or SPCA, estimated factor $\widehat{F}_{t}$ becomes an explanatory variable. The next step is then to estimate the parameters $\left(\beta_{W}, \beta_{F}\right)$ of (1). Since factors are constructed without considering the dependent variable, we use shrinkage methods to give more weight to the selected factors. Brief introductions of shrinkage methods are provided as follow (see Kim and Swanson (2013a,b) for more details):

- Bagging (Bootstrap Aggregating): Bagging, introduced by Breiman (1996), makes bootstrapped samples from an original set, forecasts the target variable from each bootstrapped sample, and then takes the average of these forecasts, which becomes the bagging predictor. Stock and Watson (2012) modify bagging to make the algorithm similar to an ordinary shrinkage method by including a shrinkage factor, and apply it for forecasting U.S. macroeconomic variables under the FAAR model.

- Boosting: Introduced by Freund and Schapire (1997), boosting is a procedure 
that builds on a user-determined set of functions (e.g. least square estimators), often called "learners", and uses this set iteratively on filtered data by reducing the residuals in the previous iteration. Boosting is not strictly speaking a shrinkage method, but it resembles the procedure of bagging and is known to perform well in the forecasting literature (see Bai and Ng (2009)).

- Ridge Regression: Ridge, introduced by Hoerl and Kennard (1970), is one of the earliest versions of a penalized regression. By imposing an $L_{2}$ penalty on loss function it gives very tiny, but not zero, coefficients on less important variables. This is similar to following methods, which are penalized regressions characterized by a $L_{1}$ penalty function, which directly gives zero coefficients to the selected variables. ${ }^{4)}$

- Least Angle Regression (LARS): This method was introduced by Efron et al. (2004). LARS, like stepwise regressions, uses the residuals obtained after regressing the target variable on one of the explanatory data and constructs the first estimate, and then decides whether that each series can be part of the active set or not. Possible explanatory variables are incrementally examined, of which only some have corresponding non-zero coefficients then participate in making the final LARS estimate.

- Elastic Net (EN): Zou and Hastie (2005) introduced EN to overcome the problems found in LARS when $T$ is larger than $N$. EN is basically similar to LARS as a penalized regression, but uses $L_{1}$ and $L_{2}$ penalties simultaneously.

- Non-negative Garrote (NNG): Breiman (1995) introduced this method, and Yuan and Lin (2007) modified the algorithm using EN. Since NNG is based on the least square estimator, its use in simple implementation is advantageous.

We also consider an autoregressive model (AR), an autoregression with exogenous variables (ARX), and a combined autoregressive distributed lag (CADL) as benchmark models. We in addition estimate the FAAR model, equivalent to equation (1) using the least square, and carry out the same estimation without lagged terms, which is called principal component regression (PCR). Also considered in

4) See Hoerl and Kennard (1970) for $L_{2}$ penalty and Tibshirani (1996) for $L_{1}$ penalty. 
the sequel is Bayesian Model Averaging (BMA), known in the relevant literature as the best performer in an empirical sense. Table 1 lists all of the estimation methods used in this paper. The methods ranging from FAAR to NNG in Table 1 are based on the FAAR framework of (1), while AR, ARX and CADL do not contain any factors. We also refer to the models from Bagg to NNG as "hybrid" models, since they combine factors with shrinkage methods in their estimations.

In summary, we estimate $\widehat{F}_{t}$ as a first step using PCA and SPCA, and then estimate $\widehat{\beta_{W}}, \widehat{\beta_{F}}$ using various shrinkage methods as a second step to forecast $\widehat{Y_{t+h}} .5$ )

Table 1: Models and Methods Used in Forecasting Experiment

\begin{tabular}{l|l}
\multicolumn{1}{c|}{ Method } & \multicolumn{1}{c}{ Description } \\
AR & Autoregressive model with lags selected by the SIC \\
\hline ARX & Autoregressive model with exogenous regressors \\
\hline CADL & Combined autoregressive distributed lag model \\
\hline FAAR & Factor augmented autoregressive model estimated by OLS \\
\hline PCR & Principal component regression \\
\hline Bagg & Bootstrap aggregating \\
\hline Boost & Component boosting \\
\hline BMA1 & Bayesian Model Averaging with g-prior=1/T \\
\hline BMA2 & Bayesian Model Averaging with g-prior=1/N2 \\
\hline Ridge & Ridge regression \\
\hline LARS & Least angle regression \\
\hline EN & Elastic net \\
\hline NNG & Non-negative garotte \\
\hline Mean & Arithmetic mean of all above \\
\hline
\end{tabular}

Notes: This table summarizes the model specification and estimations used in the construction of prediction models.

5) Kim and Swanson (2013b) consider the dynamics in the factors, and show that they do not help to improve predictive accuracy, and we therefore also decide not to consider them as well. 


\section{Sparse Principal Component Analysis}

We skip explanation of PCA, as it was already been discussed in various literature. As explained in the previous section, the principal components are linear combinations of variables that are ordered by covariance contribution. As a result, the loading coefficients are all nonzero, making it difficult to interpret what each component represents. SPCA aids in the interpretation of PCA by restricting some coefficients at zero, we thus have components that are the linear combinations of only some of the variables. Joliffe et al. (2003), at first, suggested SCoTLASS for constructing modified principal components with possible zero loadings but the constraint of the method does not ensure convexity so that the estimation is computationally expensive. Then Zou et al. (2006) developed a regression optimization framework to derive sparse loading coefficients, and named it SPCA, which has less computational burden and we follow their approach in the spirit of Kim and Swanson (2013b).

Suppose we derive factors, $F$ via ordinary PCA. In particular, a standardized data matrix, $X$ can be decomposed to $U D V^{\prime}$ by singular value decomposition. In ordinary PCA, $F$, is defined as $U D$, and $V$ becomes the loading. We then consider a simple regression problem like (2) to obtain sparse loadings by letting $F_{i}$, the $i$-th principal component be a dependent variable and $X$ be explanatory variables. That is, the SPCA problem can be switched to a penalized regression problem. Zou et al. (2006) suggested the following regression type criterion to obtain sparse loadings by solving the problem: Let $X_{t}$ be the $t$-th row vector of $X$; then for any positive value of $\eta$,

$$
\begin{gathered}
\left(\hat{\delta_{j}}, \widehat{\lambda_{j}}\right)=\arg \min _{\delta_{i}, \lambda_{j}} \sum_{t=1}^{T}\left\|X_{t}-\delta_{j} \lambda_{j}^{\prime} X_{t}\right\|^{2}+\eta\left\|\lambda_{j}\right\|^{2} \\
\text { subject to }\left\|\delta_{j}\right\|^{2}=1 .
\end{gathered}
$$

Then $\hat{\lambda_{j}}$ becomes the estimator of the $j$-th loading, $\lambda_{j}$. We can then simply extend (4) to derive a whole sequence of PCs. However, the penalty parameter $\eta$ is applied to all variables, and this means that we do not have sparsity yet. By giving a 
lasso penalty $\left.{ }^{6}\right)$ term, which is the $L_{1}$ penalty, we can consider the following penalized regression problem in obtaining the sparse loadings:

$$
\begin{gathered}
(\widehat{\Delta}, \hat{\Lambda})=\arg _{\min } \sum_{t=1}^{T}\left\|X_{t}-\Delta \Lambda^{\prime} X_{t}\right\|^{2}+\eta \sum_{j=1}^{r}\left\|\lambda_{j}\right\|^{2}+\sum_{j=1}^{r} \eta_{1, j}\left\|\lambda_{j}\right\|_{1} \\
\text { subject to } \Delta^{\prime} \Delta=I_{r}
\end{gathered}
$$

where $\Lambda$ is an $N \times r$ matrix with column $\lambda_{j}$, and $\Delta$ is also an $N \times r$ orthogonal constraint, so that $\hat{\lambda_{j}}$ is the estimator of the $j$-th factor loadings, $\lambda_{j}$. See Zou et al. (2006) and Kim and Swanson (2013b) for more computational details. The SPCA algorithm, which solves (5) as follows.

\section{Algorithm Sparse Principal Component Analysis}

1. Let $\Delta$ be the factor loadings of the first $r$ principal components.

2. Given $\Delta$, solve the following regression problem for $j=1,2, \ldots, r$.

$$
\lambda_{j}=\operatorname{argmin} \min _{\lambda}\left(\delta_{j}-\lambda\right)^{\prime} X^{\prime} X\left(\delta_{j}-\lambda\right)+\eta\|\lambda\|^{2}+\eta_{1, j}\|\lambda\|_{1}
$$

3. For each fixed $\Lambda=\left[\lambda_{1}, \ldots, \lambda_{r}\right]$, do the singular value decomposition on $X^{\prime} X \Lambda=U D V^{\prime}$, then update $\Delta^{*}=U V^{\prime}$

4. Repeat steps 2-3 until convergence. In the final loop, $\Delta^{*}$ becomes the sparse factor loadings.

There are two parameters for obtaining sparse loadings and in practice, the choice of $\eta$ is known not to affect the result much. However, the sparsity of loadings depends greatly upon another parameter, $\eta_{j}$. Shen and Huang (2007) introduce two ways of selecting the tuning parameters. The first method is $K$-fold Cross Validation (CV) which chooses the degree of sparsity where a given CV is minimized. The other is using the cumulative percentage of the explained variance (CPEV) of the first $r$ PCs. The degree of sparsity as the largest parameter can be selected where the CPEV does not drop too much (for example, by less than $5 \%$ or $10 \%$ ) from its peak value. For computational brevity we follow this second approach,

6) See Tibshirani (1996) for details about the lasso (least absolute shrinkage and selection operator) penalty 
which Shen and Huang (2007) state also works reasonably well.

\section{Data and Estimation}

We do not restrict which series are included in the predictor set, since the purpose of this paper is extracting useful information from a large set of data. We therefore collect all available monthly series from 1970. We consider both aggregate and disaggregate series at the same level since multicollinearity does not occur in the construction of factors using PCA (see Stock and Watson (2002)).

We collect 617 monthly series from January 1970 to December 2012 and categorize them into 12 groups: interest rates, imports/exports, prices, money, exchange rates, orders received, inventories, housing, retail and manufacturing, employment, industrial production, and stocks. Among these, we pick 340 series which do not have missing values and have at least 120 observations. ${ }^{7)}$ The variables selected are listed in Appendix 1.

Since most of the data are available only in recent periods, and their starting dates are various, we only consider a rolling estimation scheme where we have 120 observations as the rolling window. When a series completes 120 observations, it is eligible for inclusion in the predictor set used in the estimation. We therefore have a set of predictors that increases in size from period to period.

7) In the estimation, we consider 120 for the size of the in-sample, and for that reason we limit the data to those with at least 120 observations. 
Figure 1: Number of Variables Included in Estimation

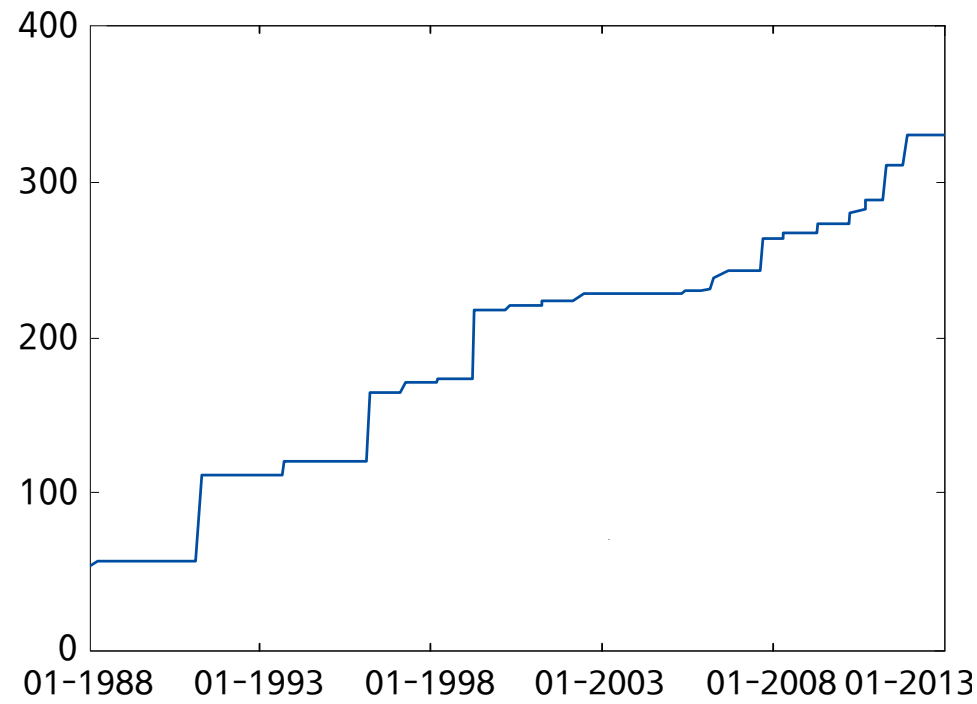

Notes: The solid line shows the number of variables actually used in each period of estimation in the out-of-sample forecasting experiment. Since many series were not available in the past, only some of them have been used in the estimation.

Figure 1 shows this increasing number of available variables over our out-ofsample period. In November 1987, we have only 58 available series, but by the end of the period, it reaches 340 . In this sense, for more a precise forecasting experiment, we need to consider a real-time dataset. We leave this to future research since a real-time dataset for Korea has not yet been established. Having a limited amount of available data in the early periods, we consider a forecasting experiment only for the recent 10 years, which is from 2002:01 to 2012:12. Note that all variables are assumed to be stationary for implementing PCA, and we therefore transform the data appropriately following Stock and Watson (2012).

The purpose of estimating principal components is reducing the data dimension, which means that we have to choose a "small" number of components that contain a large enough amount of information from the predictor set. Bai and $\mathrm{Ng}$ (2002) provide one solution to the problem of choosing the number of factors in the use of ordinary PCA. They establish convergence rates for factor estimates 
under consistent estimation of the number of factors, $r$, and propose panel criteria to consistently estimate the number of factors. Bai and $\mathrm{Ng}$ (2002) defined selection criteria of the form $P C(r)=V(r, \hat{F})+r h(N, T)$ where $h(\bullet)$ is a penalty function. In this paper, the following version is used (see Bai and Ng (2002) for more details):

$$
S I C(r)=V(r, \hat{F})+r \widehat{\sigma^{2}}\left(\frac{(N+T-r) \ln (N T)}{N T}\right)
$$

where $\widehat{\sigma^{2}}$ is $(N T)^{-1} \sum_{i=1}^{N} \sum_{t=1}^{T} \widehat{e_{i, t}}$ and $\hat{e}$ is the estimator of $e$ in (2). The consistent estimate of the number of factors is $\hat{r}=\arg \min _{0 \leqq r \leqq} r_{\max } S I C(r)$. We use this criterion in choosing the number of factors in the sequel.

Figure 2: Number of Factors Determined by BN

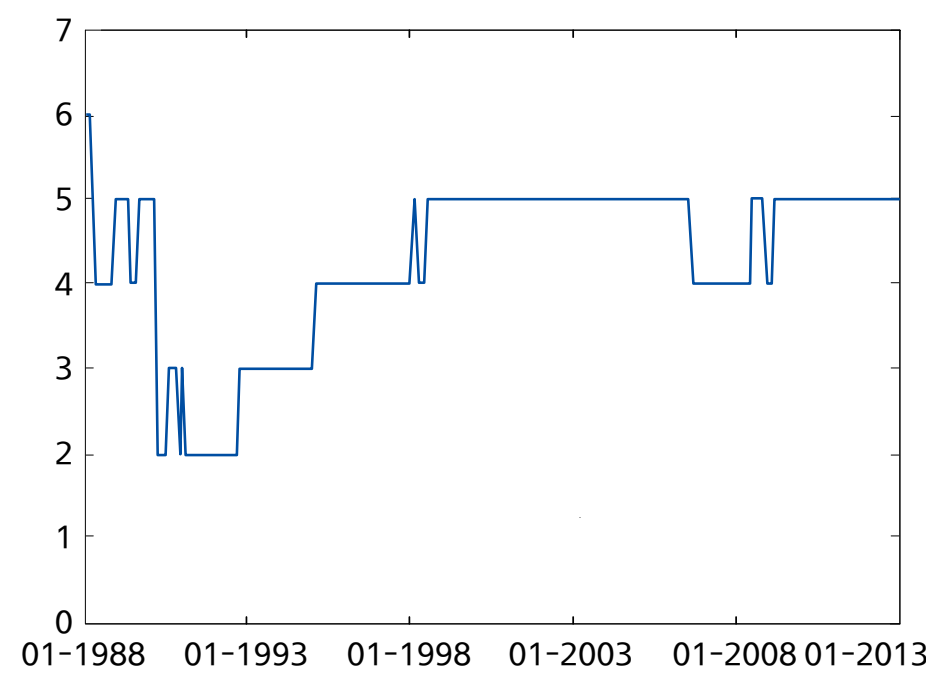

Notes: The solid line shows the number of factors determined by Bai and Ng (2002), where these factors are estimated using principal component analysis at each time of forecast. This time-varying number of factors is used in the actual forecast. 
Figure 2 shows the number of factors determined by Bai and $\mathrm{Ng}$ (2002) at each time of forecasting. We truncate the earlier sample periods for brevity and between four and five factors are selected consistently after 1995. Alhough there are continuous inputs of new series in constructing the factors, the appropriate number of factors does not seem to be affected. The above discussion is for PCA, and as there is no literature on determining the number of factors for SPCA, we use the same number of factors in PCA in the sequel.

\section{Comparison of Two Principal Components}

As explained in the previous section, many loadings by SPCA become zero, unlike in ordinary PCA. That is, the less important variables have coefficients of zero and principal components (or factors) consist of a small number of variables, which enables us to interpret what the factors are composed of.

Table 2 shows the selected loadings of the first two components of PCA and SPCA. For the readers' convenience, the first column corresponds to the numbers in the full list of all predictors in the appendix. Columns PC1 and PC2 denote the loadings of PC, and SPC1 and SPC2 those of sparse PC. Note that all variables participate in the composition of the principal components, so that all loading coefficients are non-zero. Since over 300 variables are included in composing one component, it is very difficult to confirm how each component works in the set. 
Table 2: First Two Loadings of PC and SPC in December 2012

\begin{tabular}{|c|c|c|c|c|c|c|}
\hline No. & Class & Variable & PC1 & PC2 & SPCA1 & SPCA2 \\
\hline 1 & Interest Rates & Uncollateralized Call Rate & -0.685 & -0.601 & 0 & 0 \\
\hline 19 & Trade & Unit Value Index of Imports & -0.600 & -0.691 & 0 & 0 \\
\hline 43 & Trade & Unit Value Index of Exports & -0.771 & -0.493 & 0 & 0 \\
\hline 66 & Price & Producer Price Index-All & -0.052 & -0.721 & 0 & 0 \\
\hline 74 & Price & Consumer Price Index-All & 0.191 & -0.667 & 0 & 0 \\
\hline 81 & Price & Housing Price Index & -0.285 & -0.431 & 0 & 0 \\
\hline 87 & Money & In Circulation & -0.222 & 0.097 & 0 & 0 \\
\hline 110 & Exchange Rates & Won Per Japanese Yen & 0.781 & -0.239 & 0 & 0 \\
\hline 123 & Order Received & Machinery & 0.149 & 0.041 & -0.077 & 0 \\
\hline 153 & Order Received & Domestic Construction-Private & -0.425 & -0.100 & 0.054 & 0 \\
\hline 168 & Inventory & Total Index & -0.332 & -0.727 & 0 & 0 \\
\hline 197 & Housing & Unsold-Seoul & 0.166 & 0.108 & -0.033 & 0.301 \\
\hline 214 & $\begin{array}{l}\text { Retails and } \\
\text { Manufacturing }\end{array}$ & $\begin{array}{l}\text { Wholesale and Retail Sales } \\
\text { Index-All }\end{array}$ & -0.668 & -0.047 & 0 & 0 \\
\hline 249 & $\begin{array}{l}\text { Retails and } \\
\text { Manufacturing }\end{array}$ & $\begin{array}{l}\text { Manufacturing Operation Ratio } \\
\text { Index }\end{array}$ & -0.788 & 0.177 & 0 & 0 \\
\hline 276 & Employment & $\begin{array}{l}\text { Unemployed-More than } 12 \\
\text { Months. }\end{array}$ & -0.120 & 0.471 & -0.0213 & 0.1815 \\
\hline 283 & Employment & Unemployment Rate & -0.031 & 0.325 & 0 & 0 \\
\hline 304 & Stocks & KOSDAQ Construction Index & -0.830 & 0.425 & 0 & 0 \\
\hline
\end{tabular}

Notes: This table indicates the factor loadings of the first two components of PCA and SPCA. Due to limited space, we only show the loadings of selected variables. The first column shows the index numbers used in the list in the Appendix. The second one specifies the class each variable belongs to (we divide all variables into 12 classes). Since SPCA makes many variables' loadings zero, only some of the variables have nonzero loadings.

On the other hand, only a few variables participate in the composition of the components in SPCA. The first SPC in Table 2 consists of four variables and the other variables' coefficients are all zero. The actual first component consists of 47 variables out of 340 variables in total, and we report only a part of them for the sake of brevity in Table 2. SPCA enables us to construct a more parsimonious model, which is believed to give more accurate prediction according to Diebold (1998) and Clark and McCraken (2009). To analyze which variables are included the most 
in constructing factors, we count how many times each variable participates in each out-of-sample prediction.

Figure 3 shows the numbers of inclusion of variables with non-zero coefficients in the first two sparse principal components over the out-of-sample period (which is from 1982:01 to 2012:12). The left panel is for the first component and the right one for the second. 340 variables are categorized into 12 groups in the figure, with each group having the same colored bar. The most selected group is 'Orders Received' and the most selected variable in this group for both of the components is the Value of Construction Orders Received. Aggregate 'Construction Orders Received' is considered one of the components of a leading indicator, and its disaggregate series are frequently chosen in sparse principal components. This gives useful insight for future research in analyzing which series play bigger roles in the economy. Other frequently chosen variables include ones from the interest rates and the employment groups. Among interest rates, US interest rates such as Treasury Note Yield are the most selected. This may be an evidence showing that the Korean economy is affected by foreign economies, especially the US. We also include the Japanese government bond rate in our set, which does not seem as influential as the US Rates. In the employment group, the unemployment and employment rates are as expected the most chosen. Stock-related variables are frequently selected but we could not conclude which index is predominantly included over the out-ofsample periods. Surprisingly, price and money variables, which may be considered more important ex ante, are never chosen. 
Figure 3: Number of Variables with Non-zero Coefficients in Constructing the First Two Sparse Principal Components
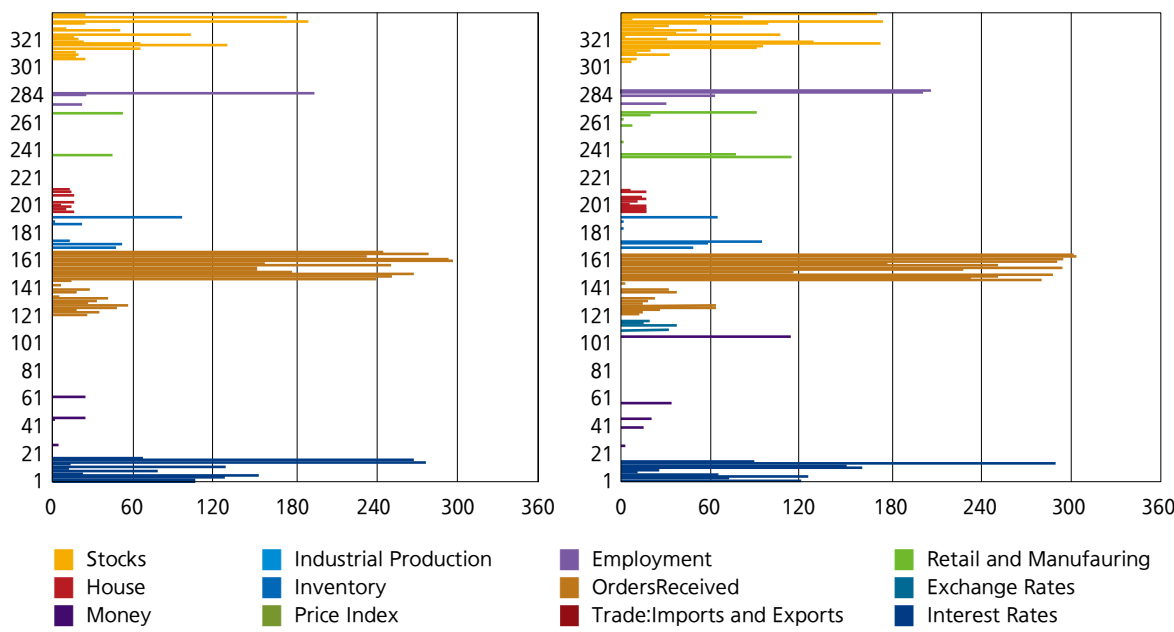

Notes: See the Appendix for the description of variables. The left panel shows the frequencies of inclusions of the explanatory variables in the first sparse principal component through the out-of-sample forecasting experiment, and the right panel the frequencies for the second sparse principal component. The vertical axis of each panel indicates the index number of variables from the Appendix. Variables from the same groups are in the same color. For example, Domestic Construction Order Received - Roads and Bridges, index \#163, is included in construction of the first sparse principal component in 297 times out of 300 out-of-sample periods.

To see how influential each variable is over the experiment period, we plot the changes in loadings of selected variables as shown in Figure 4. Due to the limited data availability, the changes in factor loadings before 1998 are too dramatic, and we therefore exclude the results of those periods. The Uncollateralized Call Rates have remained highly influential over time, except in the beginning of the sample period (because call rates were not in the dataset at that time). In this regard, the main proxy of the first component seems to be the Overnight Call Rates in the period when all predictors are included. Considering the interactions among the interest rate variables, it is not surprising that there is a shift in importance among them. Note that the weight of the US T-Note yield has risen since the 2007-08 Financial Crisis, which may indicate that influences from overseas have increased after the crisis. 
Figure 4: Factor Loadings of Selected Variables in First Two Components
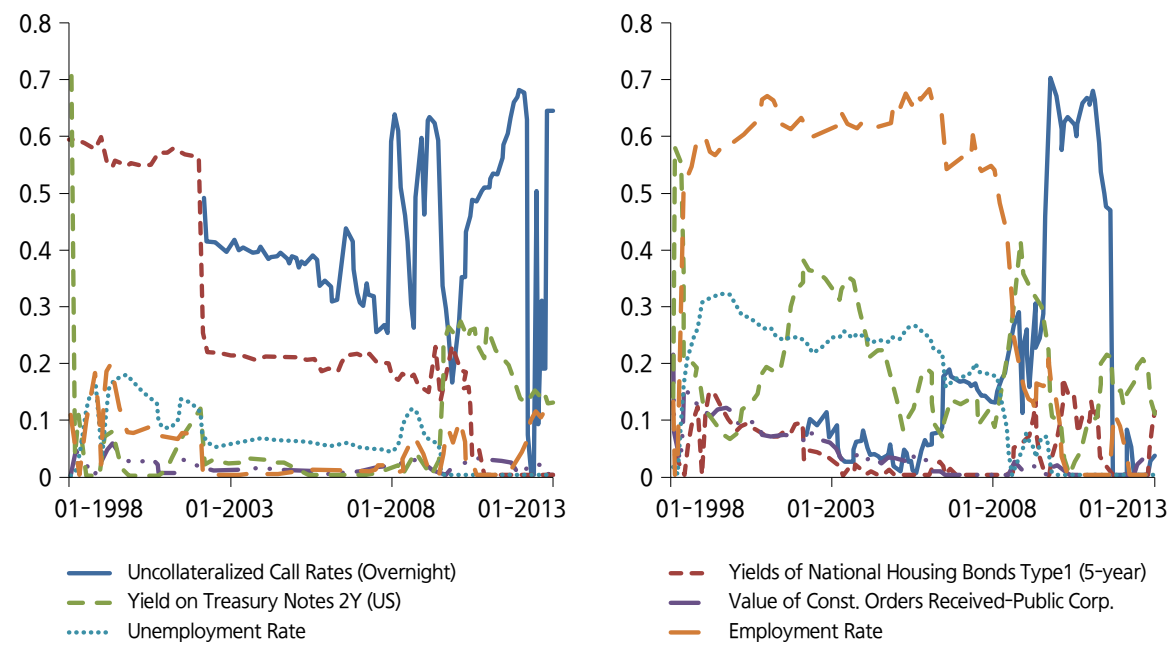

Notes: See notes to Figure 3. The left panel shows the changes in loadings of the selected variables of the first sparse principal component and the right one the second sparse principal component over 1998:01-2012:12.

In the first component, variables other than interest rates have had relatively smaller weights. In the second component, however, the value of construction orders received had more weight at the beginning of the sample period. On the other hand, the importance of the employment rate had been high in the earlier period of out-of-sample experiment but dropped after the recent financial crisis in 2008 with the importance of call rates increasing during the crisis. Number of Unsold Houses in Lots, which is included in constructing factors from 2011:09, dominates the other variables in the second component. ${ }^{8)}$ Moreover, the weight of the Yield of US T-Note fluctuates moderately even after other interest rate variables are included, and that of the employment rate, which had risen to take a dominant position in the component, dropped during the 2007-08 financial crisis. Although the variables of the Value of Construction Orders are selected the most during experiment periods, they are not considered as important now as they were in the

8) Note that we do not plot it in the figure, due to data availability, but it is necessary to monitor in the future. 
past. We can conclude that the main part of the first component is interest rates, although the relative importance among interest rates have not yet been specified. In the second component, it is not clear which variable is more dominant than the others in our sample period.

As sparse principal components consist of a smaller number of variables, they may not explain the variations in the predictor set as much as ordinary principal components do. To see this difference, we draw the cumulative percentages of explained variance (CPEV) in Figure 5. Once a group of variables get in the dataset considered, as shown in Figure 1, its percentage changes dramatically in both principal component cases. ${ }^{9)}$ However, there was a big jump in percentages in 2002 even though there were no huge increases in sets of available variables. And this high explanatory power was maintained until the Financial Crisis in 2008. This power is jointly analyzed with the forecasting accuracy of the FAAR model in the following section. The CPEV of the six sparse components have been diminishing in recent periods more dramatically than those of the six ordinary components have. Since we do not so far have any consensus on a method of determining the number of sparse components, we keep the same number of ordinary principal components and leave to future research the task of deciding an appropriate number of sparse factors to explain an satisfactory amount of variances in the predictor.

9) Since our predictor set is expanding over time, there are jumps in the CPEV. 
Figure 5: Cumulative Percentage of Explained Variance of Components

(a) CPEV of PCA

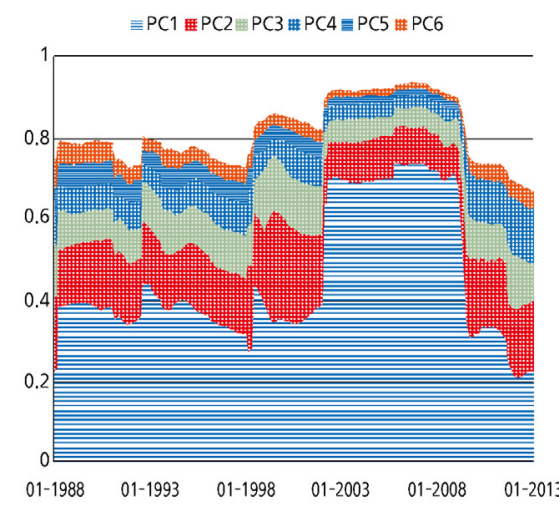

(b) CPEV of SPCA

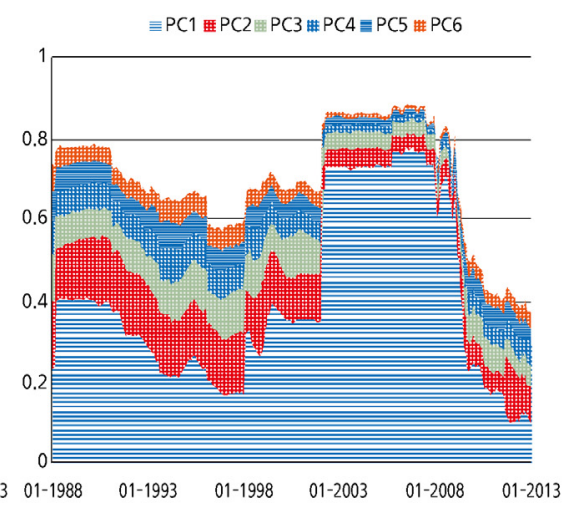

Notes: See the notes to Figures 3 and 4 . This figure plots the cumulative percentages of the explained variances of the components using PCA in Panel (a) and SPCA in Panel (b) over the forecasting experiment period.

\section{Experimental Results}

\section{Experimental Setup}

To measure the performances of the models, we use the mean square forecasting error (MSFE) method. The MSFE of the $i$-th model for $h$-step ahead is

$$
\operatorname{MSFE}_{i, h}=\sum_{t=R-h+2}^{T-h+1}\left(Y_{t+h}-\hat{Y}_{i, t+h}\right)^{2}
$$

where $R$ is a rolling window of a rolling scheme, $T$ is the number of total observations, $Y_{t+h}$ is the observed value at $t+h$, and $\hat{Y}_{i, t+h}$ is the predicted value at $t+h$ of the $i$-th model. We test the performance of the model by defining how it differs statistically from an autoregressive model, in accordance with Diebold and Mariano (1995, hereafter DM). The null hypothesis of the test is that the two models' prediction errors are identical, and is defined as 


$$
H_{0}: E\left[l\left(\epsilon_{t+h \mid t}^{1}\right)\right]-E\left[l\left(\epsilon_{t+h \mid t}^{2}\right)\right]=0
$$

where $\epsilon_{t+h \mid t}^{i}$ is the prediction error of the $i$-th model, and $l(\bullet)$ is the quadratic loss function. For example, if a statistic under the null hypothesis as in (4) is negative and significantly different from zero, we decide that model 2 outperforms model 1. The statistic of the DM test is

$$
D M=\frac{1}{P} \sum_{i=1}^{P} \frac{d_{t}}{\hat{\sigma}_{\bar{d}}}
$$

where $d_{t}=\left(\widehat{\epsilon_{t+h \mid t}^{1}}\right)^{2}-\left(\widehat{\epsilon_{t+h \mid t}^{2}}\right)^{2}, \bar{d}$ is the mean of $d_{t}, \hat{\sigma}_{\bar{d}}$ is the heteroskedasticity and autocorrelation robust estimator of the standard deviation of $\bar{d}$, and $\widehat{\epsilon_{t+h \mid t}^{1}}$ and $\widehat{\epsilon_{t+h \mid t}^{2}}$ are the estimators of the prediction errors, $\epsilon_{t+h \mid t}^{1}$ and $\epsilon_{t+h \mid t}^{2}$. In this paper, we set the autoregressive as the first model and each of all the others as the second one.

We consider the following as our target variables: consumer price index (CPI), GDP, consumption, exports and gross capital formation (GCF). Since GDP, consumption, exports and GCF are quarterly data, they are interpolated using the Industrial Production, Retail Sales Value, Value of Exports and Total Equipment indexes respectively, based on the method of Chow and Lin (1971). In line with data availability, we implement out-of-sample forecasting for prices, and consumption from 1982:11, GDP from 1992:11, exports from 2000:05 and GCF from 2007:07. Due to a shortage of data, we only consider the recent ten years' out-ofsample forecasting. We make a month, a quarter, half-a-year and a year ahead forecasts, which are denoted by $h=1,3,6$ and 12 respectively.

\section{Results: Consumer Price Index}

Table 3 reports the mean square forecasting errors (MSFEs) of the forecasts for month-on-month consumer price index inflation in the recent 10-year out-of-sample 
experiment. Entries in the first row, corresponding to our benchmark AR model, are the actual MSFEs, while the following entries are the relative MSFEs compared to those of AR model. That is, numerical values less than unity indicate cases in which the alternative model has a lower point MSFE than AR model. For example, in the one month ahead forecast, the relative MSFE of the FAAR model is 0.868 , meaning that the real MSFE is $86.8 \%$ that of AR model. Entries in bold denote the "best" performing models under the given factor methods and forecast horizons. Entries in red indicate the lowest-MSFE models between PCA and SPCA in the given forecast horizons. For example, in the one quarter ahead forecast, Mean has the lowest MSFE in both principal component methods but Mean of PCA is highlighted in red since it has lower MSFE than that of SPCA. The results of the DM predictive accuracy test between the benchmark model and the other models, listed in the first column of the table, are reported using single star (denoting rejection at the $10 \%$ level) and a double star (denoting rejection at the $5 \%$ level).

Table 3: Relative MSFEs for Month-on-Month CPI Inflation

\begin{tabular}{c|c|c|c|c|c|c|c|c}
\multirow{2}{*}{ Method } & \multicolumn{7}{|c|}{ PCA } \\
\cline { 2 - 9 } AR & $h=1$ & $h=3$ & $h=6$ & $h=12$ & $h=1$ & $h=3$ & $h=6$ & $h=12$ \\
\hline ARX & 0.001 & 0.002 & 0.002 & 0.001 & 0.001 & 0.002 & 0.002 & 0.001 \\
\hline CADL & 1.046 & 1.263 & 1.189 & $1.447^{*}$ & 1.046 & 1.263 & 1.189 & $1.447^{*}$ \\
\hline FAAR & 0.868 & 0.986 & 1.050 & 1.035 & 0.872 & 0.900 & $0.913^{*}$ & 0.913 \\
\hline PCR & 0.901 & 1.064 & 1.009 & $1.222^{* *}$ & 0.956 & $1.105^{*}$ & $0.787^{*}$ & 0.962 \\
\hline Bagg & 1.001 & 0.975 & 0.986 & 0.923 & 0.923 & 0.893 & 0.898 & 0.907 \\
\hline Boost & 0.944 & 1.008 & 1.007 & 1.022 & 0.973 & $1.054^{*}$ & 0.982 & 1.002 \\
\hline BMA1 & 0.935 & 0.998 & 1.005 & 1.008 & 0.994 & $1.054^{*}$ & 0.981 & 1.004 \\
\hline BMA2 & 0.922 & 0.997 & 1.008 & 1.019 & 0.997 & 1.064 & 0.975 & 1.015 \\
\hline Ridge & $0.904^{*}$ & 0.997 & 1.018 & 1.031 & 0.854 & $0.925^{*}$ & 0.821 & 0.828 \\
\hline LAR & 0.960 & 1.004 & 1.008 & 0.992 & 0.986 & 1.053 & 0.984 & 1.026 \\
\hline EN & 0.960 & 1.004 & 1.008 & 0.992 & 0.986 & 1.051 & 0.984 & 1.023 \\
\hline NNG & 0.962 & 1.006 & 1.017 & 1.001 & 0.994 & 1.066 & 0.979 & 1.003 \\
\hline Mean & $0.883^{*}$ & $0.972^{*}$ & 0.984 & 0.983 & $0.802^{* *}$ & 0.870 & $0.814^{*}$ & 0.805 \\
\hline
\end{tabular}


Notes: Numerical entries in this table indicate the mean square forecasting errors (MSFEs) of forecasting methods in the first column. Entries in the first row are actual MSFE of AR model while all following entries are relative MSFEs, compared to those of AR model, such that numerical values less than unity indicate cases in which the alternative model has a lower point MSFE than AR. Entries in bold denote the "best" performing models for the given forecast horizons. Entries in red denote better models, between PCA and SPCA. The results of Diebold and Mariano (1995)'s predictive accuracy tests, for which the null hypothesis is that of equal predictive accuracy between the benchmark model (defined to be the AR), and the model listed in Table 1, are reported using a single star (denoting rejection at the $10 \%$ level), and a double star (denoting rejection at the $5 \%$ level). Note that numerical entries for AR, ARX and CADL in PCA and SPCA are identical each other since those benchmark models do not involve factor or shrinkage methods.

With the exception of the one year ahead forecasts of PCA, Mean has the lowest MSFE in other horizons. Considering that model averaging or model combination outperforms other models in various literature, this is not surprising. However, applying this model in practice is a different story because the choice of which models to adopt or how to combine them matters. We discuss issues regarding this combination in the future research.

In one month ahead forecasts, the hybrid models (except Bagg) outperform AR model when PCA is used as the factor estimation method, altough only some of them outperform AR model as the forecast horizon lengthens. Bagging of PCA has the lowest MSFE in one year ahead forecast, and also has relatively lower ones in a quarter and half-a-year ahead forecasts. Overall, we cannot pick a dominant model among the hybrid models for the given forecast horizons and factor methods. However, we confirm that the mean of many forecasts work well in any case, especially when the factors are estimated by SPCA. 
Table 4: Relative MSFEs for Year-on-Year CPI Inflation

\begin{tabular}{c|l|l|l|l|l|l|l|l}
\multirow{2}{*}{ Method } & \multicolumn{9}{|c|}{ PCA } & \multicolumn{5}{c|}{ SPCA } \\
\cline { 2 - 9 } & $h=1$ & $h=3$ & $h=6$ & $h=12$ & $h=1$ & $h=3$ & $h=6$ & $h=12$ \\
\hline AR & 0.002 & 0.006 & 0.010 & 0.012 & 0.002 & 0.006 & 0.010 & 0.012 \\
\hline ARX & $1.505^{*}$ & 1.000 & 1.000 & 1.000 & $1.505^{*}$ & 1.000 & 1.000 & 1.000 \\
\hline CADL & $1.189^{*}$ & 1.105 & $1.145^{* *}$ & $1.873^{* *}$ & $1.189^{*}$ & 1.105 & $1.145^{* *}$ & $1.873^{* *}$ \\
\hline FAAR & 1.140 & 1.126 & $0.705^{*}$ & $0.398^{* *}$ & 1.113 & 1.090 & 0.900 & 0.971 \\
\hline PCR & $1.519^{*}$ & 1.027 & 0.746 & $0.387^{* *}$ & $6.593^{* *}$ & $1.927^{*}$ & 1.055 & $1.369^{* *}$ \\
\hline Bagg & $2.520^{* *}$ & $2.286^{* *}$ & 0.991 & 0.947 & 1.060 & 1.043 & $1.360^{*}$ & $1.718^{* *}$ \\
\hline Boost & 1.075 & 1.120 & $0.803^{*}$ & $0.461^{* *}$ & 0.993 & 1.005 & 0.937 & 0.941 \\
\hline BMA1 & 1.061 & 1.234 & 0.847 & $0.485^{* *}$ & 1.024 & 1.054 & 0.974 & $1.163^{*}$ \\
\hline BMA2 & 1.066 & 1.227 & 0.821 & $0.499^{* *}$ & 1.035 & 1.066 & 0.993 & $1.164^{*}$ \\
\hline Ridge & 1.074 & 1.249 & 0.880 & $0.398^{* *}$ & 1.060 & 1.018 & 0.955 & 1.015 \\
\hline LAR & 1.007 & 1.019 & $0.959^{* *}$ & $0.959^{* *}$ & 0.984 & 0.991 & $0.983^{*}$ & $1.047^{*}$ \\
\hline EN & 1.007 & 1.018 & $0.959^{* *}$ & $0.959^{* *}$ & 0.984 & 0.991 & $0.984^{*}$ & $1.044^{*}$ \\
\hline NNG & 1.017 & 1.016 & $0.975^{* *}$ & 0.996 & 0.981 & 0.998 & 0.990 & 1.007 \\
\hline Mean & $0.944^{*}$ & 0.928 & $0.686^{* *}$ & $0.540^{* *}$ & 1.039 & 0.975 & 0.890 & 0.916 \\
\hline
\end{tabular}

Notes: See notes to Table 3.

Table 4 shows the relative MSFE for year-on-year CPI inflation over the same period in the previous year like Table 3. The overall performances of the one month and one quarter ahead forecasts of the hybrid models are not dominant over those of AR model. Especially, no one month or one quarter ahead forecasts of any of the hybrid models using PCA ever outperform AR model. In the meantime, some of the models using SPCA work better than AR model in given forecast horizons. However, as the forecasting horizon becomes longer, in half-a-year and one year ahead forecasts, the hybrid models show much better statistics than AR model does. Specifically, in a year ahead forecast, the relative MSFE of FAAR under PCA is about $60 \%$ lower than that of AR. Mean of PCA in this longer forecast horizons also works much better than that shorter forecast horizons. As can be seen later, this results is similar for all the other variables. Overall, we can conclude that FAAR and PCR work relatively well in longer forecast horizons when the factors are estimated by PCA. 


\section{Results: GDP growth rate}

Entries in Tables 5 and 6 are the relative MSFEs of the forecasts for the GDP growth rate over the previous month and over the same month in the previous year, respectively. Interestingly, Table 5 shows that, for any forecast horizons, the models using SPCA work better than those using PCA. However, the best-MSFE model in SPCA is not significantly different from the MSFE of AR model. The forecasting of month-on-month growth rates shows results similar to those for CPI inflation. That is, for shorter forecast horizons, not many methods beat AR model in forms of MSFE but for longer horizons, the methods using PCA perform better. However, the best models, especially when using PCA, are generally the means of all the other models (Mean). This again confirms the well-known result that model averaging or forecast combination works well in practice.

\section{Table 5: Relative MSFEs for Month-on-Month GDP Growth}

\begin{tabular}{c|c|c|c|c|c|c|c|c}
\multirow{2}{*}{ Method } & \multicolumn{9}{|c|}{ PCA } & \multicolumn{7}{c|}{ SPCA } \\
\cline { 2 - 9 } & $h=1$ & $h=3$ & $h=6$ & $h=12$ & $h=1$ & $h=3$ & $h=6$ & $h=12$ \\
\hline AR & 0.027 & 0.030 & 0.031 & 0.033 & 0.027 & 0.030 & 0.031 & 0.033 \\
\hline ARX & 1.059 & 1.149 & 1.211 & 1.105 & 1.059 & 1.149 & 1.211 & 1.105 \\
\hline CADL & 1.086 & 1.025 & 1.037 & 1.021 & 1.086 & 1.025 & 1.037 & 1.021 \\
\hline FAAR & 1.086 & 1.050 & 1.052 & 1.093 & 1.046 & 1.052 & 1.021 & 1.061 \\
\hline PCR & 1.242 & 1.061 & 1.034 & 1.043 & 1.267 & 1.032 & 0.968 & 0.935 \\
\hline Bagg & 1.043 & 1.017 & 1.005 & 1.019 & 1.016 & 1.019 & 1.018 & 1.016 \\
\hline Boost & 1.026 & 1.012 & 1.013 & 1.007 & 1.056 & 0.996 & 0.994 & 0.994 \\
\hline BMA1 & 1.022 & 1.005 & 1.007 & 1.012 & 1.060 & 0.997 & 0.993 & 0.993 \\
\hline BMA2 & 1.028 & 1.011 & 1.014 & 1.016 & 1.059 & 0.996 & 0.990 & 0.993 \\
\hline Ridge & 1.036 & 1.013 & 1.014 & 1.039 & 1.019 & 1.001 & 0.988 & 0.988 \\
\hline LAR & 1.012 & 1.018 & 1.020 & 1.009 & 1.026 & 1.000 & 0.994 & 1.001 \\
\hline EN & 1.012 & 1.018 & 1.020 & 1.009 & 1.026 & 1.000 & 0.994 & 1.001 \\
\hline NNG & 1.014 & 1.020 & 1.033 & 1.009 & 1.020 & 1.005 & 0.989 & 1.008 \\
\hline Mean & 0.988 & 1.011 & 1.017 & 1.002 & 0.987 & 0.998 & 0.993 & 0.979 \\
\hline
\end{tabular}

Notes: See notes to Table 3. 
Table 6: Relative MSFEs for Year-on-Year GDP Growth

\begin{tabular}{c|c|c|c|c|c|c|c|c}
\multirow{2}{*}{ Method } & \multicolumn{9}{|c|}{ PCA } & \multicolumn{5}{c}{ SPCA } \\
\cline { 2 - 9 } & $h=1$ & $h=3$ & $h=6$ & $h=12$ & $h=1$ & $h=3$ & $h=6$ & $h=12$ \\
\hline AR & 0.048 & 0.062 & 0.061 & 0.064 & 0.048 & 0.062 & 0.061 & 0.064 \\
\hline ARX & 0.955 & 0.822 & 0.943 & 0.906 & 0.955 & 0.822 & 0.943 & 0.906 \\
\hline CADL & 1.135 & 1.243 & 1.230 & $1.640^{*}$ & 1.135 & 1.243 & 1.230 & $1.640^{*}$ \\
\hline FAAR & $1.160^{*}$ & 0.857 & 0.825 & 0.735 & 0.991 & 0.894 & 0.979 & 0.957 \\
\hline PCR & $1.167^{*}$ & 0.925 & 0.837 & 0.883 & 1.250 & 1.031 & 1.215 & 0.912 \\
\hline Bagg & 1.368 & 0.885 & 1.006 & 0.941 & 1.014 & 1.025 & 1.079 & $0.788^{*}$ \\
\hline Boost & 1.009 & 1.013 & 0.825 & 0.790 & 1.002 & 1.068 & $1.218^{* *}$ & 0.980 \\
\hline BMA1 & 1.014 & 1.055 & 0.835 & 0.812 & 1.009 & 1.107 & $1.312^{* *}$ & 1.054 \\
\hline BMA2 & 1.017 & 1.030 & 0.836 & 0.859 & 1.010 & $1.106^{*}$ & $1.311^{* *}$ & 1.052 \\
\hline Ridge & 1.012 & 1.042 & 0.844 & 0.743 & 1.006 & 1.099 & $1.259^{*}$ & 0.935 \\
\hline LAR & 1.002 & 0.971 & 0.952 & $0.923^{* *}$ & 0.999 & 1.005 & 1.011 & $0.918^{*}$ \\
\hline EN & 1.002 & 0.971 & 0.952 & $0.922^{* *}$ & 0.999 & 1.005 & 1.011 & $0.918^{*}$ \\
\hline NNG & 1.004 & 0.969 & 0.970 & $0.988^{*}$ & 1.001 & 0.995 & 1.007 & $0.990^{*}$ \\
\hline Mean & 0.951 & 0.855 & $0.801^{*}$ & $0.723^{*}$ & $0.941^{*}$ & $0.941^{*}$ & 1.008 & $0.851^{* *}$ \\
\hline
\end{tabular}

Notes: See notes to Table 3.

\section{Results: Consumption}

Tables 7 and 8 report the relative MSFEs of the forecasts for consumption over the previous month and over the same month in the previous year respectively. Note that the results in both tables are for the recent five years' out-of-sample forecasting experiment due to the data availability of the corresponding series when implementing interpolation. In Table 7, not many hybrid models work better than AR model for any forecast horizons, as is already known from the previous forecasts. However, Bagg performs well and has the lowest MSFE in one month and one quarter ahead forecasts using all types of factor methods. In year-on-year consumption growth rate forecast as in Table 8, the models using PCA work better. Moreover, as shown in the previous forecasts, the performances of the hybrid models seem better with the longer forecast horizons, although they are not as good as in CPI inflation or the GDP growth rate percent. 
Table 7: Relative MSFEs for Month-on-Month Consumption Growth

\begin{tabular}{c|l|l|l|l|l|l|l|l}
\multirow{2}{*}{ Method } & \multicolumn{9}{|c|}{ PCA } & \multicolumn{7}{c|}{ SPCA } \\
\cline { 2 - 9 } & $h=1$ & $h=3$ & $h=6$ & $h=12$ & $h=1$ & $h=3$ & $h=6$ & $h=12$ \\
\hline AR & 0.010 & 0.013 & 0.013 & 0.012 & 0.010 & 0.013 & 0.013 & 0.012 \\
\hline ARX & $1.881^{*}$ & $1.312^{*}$ & 1.290 & 1.309 & $1.881^{*}$ & $1.312^{*}$ & 1.290 & 1.309 \\
\hline CADL & 1.083 & 1.000 & 0.995 & 1.020 & 1.083 & 1.000 & 0.995 & 1.020 \\
\hline FAAR & 1.035 & 1.066 & 1.142 & 1.090 & 1.045 & 1.142 & 1.006 & 0.954 \\
\hline PCR & 1.406 & 1.059 & 1.148 & 1.123 & 1.395 & 1.045 & 1.096 & 1.147 \\
\hline Bagg & 0.994 & 0.997 & 1.010 & 0.997 & 0.952 & 0.990 & 1.037 & 1.032 \\
\hline Boost & 1.007 & 1.027 & 1.019 & 1.037 & 0.978 & 0.993 & 1.019 & 1.023 \\
\hline BMA1 & 0.997 & 1.018 & 1.019 & 1.016 & 1.006 & 1.015 & 1.004 & 1.038 \\
\hline BMA2 & 1.002 & 1.025 & 1.034 & 1.024 & 1.015 & 1.021 & 1.009 & 1.040 \\
\hline Ridge & 1.000 & 1.023 & 1.041 & 1.027 & 1.021 & 1.018 & 1.016 & 1.039 \\
\hline LAR & 1.000 & 1.037 & 1.022 & 1.045 & 0.991 & 1.024 & 1.014 & 1.011 \\
\hline EN & 1.000 & 1.036 & 1.021 & 1.043 & 0.991 & 1.024 & 1.014 & 1.010 \\
\hline NNG & 1.007 & 1.052 & 1.047 & 1.072 & 0.988 & 1.015 & 1.049 & 0.996 \\
\hline Mean & 1.022 & 1.028 & 1.030 & 1.024 & 1.019 & 1.009 & 1.014 & 0.971 \\
\hline
\end{tabular}

Notes: See notes to Table 3.

Table 8: Relative MSFEs for Year-on-Year Consumption Growth

\begin{tabular}{c|c|c|c|c|c|c|c|c}
\multirow{2}{*}{ Method } & \multicolumn{9}{|c|}{ PCA } & \multicolumn{5}{c}{ SPCA } \\
\cline { 2 - 9 } AR & $h=1$ & $h=3$ & $h=6$ & $h=12$ & $h=1$ & $h=3$ & $h=6$ & $h=12$ \\
\hline ARX & 0.022 & 0.024 & 0.024 & 0.028 & 0.022 & 0.024 & 0.024 & 0.028 \\
\hline CADL & 1.424 & 1.119 & 1.370 & 0.909 & 1.424 & 1.119 & 1.370 & 0.909 \\
\hline FAAR & 1.349 & 1.084 & 0.982 & 1.074 & 1.049 & 1.084 & 0.982 & 1.074 \\
\hline PCR & 1.317 & 1.111 & 0.856 & 1.080 & 1.731 & $1.885^{*}$ & 1.497 & 1.199 \\
\hline Bagg & 1.466 & $1.628^{*}$ & 1.983 & 1.123 & 1.027 & 1.014 & 0.943 & 0.975 \\
\hline Boost & 1.043 & 1.262 & 1.249 & 0.822 & 1.029 & 1.325 & 1.006 & 1.001 \\
\hline BMA1 & 1.049 & 1.399 & 1.403 & 0.936 & 1.024 & 1.455 & 1.133 & 1.164 \\
\hline BMA2 & 1.033 & 1.350 & 1.466 & 0.978 & 1.033 & 1.464 & 1.153 & 1.154 \\
\hline Ridge & 1.117 & 1.241 & 0.989 & 0.875 & 1.042 & 1.428 & 1.104 & 1.040 \\
\hline LAR & 1.002 & 0.994 & 0.988 & 0.878 & 1.017 & 1.161 & $0.920^{*}$ & 0.960 \\
\hline EN & 1.002 & 0.994 & 0.988 & 0.878 & 1.017 & 1.160 & $0.921^{*}$ & 0.960 \\
\hline NNG & 1.029 & 0.999 & 1.006 & 0.967 & $1.051^{*}$ & 1.087 & 0.960 & 0.977 \\
\hline Mean & 0.977 & 0.976 & 0.928 & 0.696 & 1.008 & $1.140^{*}$ & 0.925 & 0.799 \\
\hline
\end{tabular}

Notes: See notes to Table 3. 


\section{Results: Exports}

Table 9 shows the MSFEs of the forecasts of exports over the previous month. We can find that Mean outperforms in many cases, like with other variables. With respect to the year-on-year export growth rate, we do not find that the predictions for longer horizons are more precise than those for shorter ones, different from cases of other variables. This implicates that forecasting for exports is more difficult than other variables. Ridge has the smallest MSFE in a year ahead forecasts but shows worse results than AR in shorter horizons. We can therefore not conclude that this method is a good 'stable' performer. In the meantime, Mean still shows a good performance for the longer forecast horizons. Since the result for year-onyear growth rate resemble those of consumption like Table 8, we skip the result for brevity.

Table 9: Relative MSFEs for Month-on-Month Growth in Exports

\begin{tabular}{c|l|l|l|l|l|l|l|l}
\multirow{2}{*}{ Method } & \multicolumn{9}{|c|}{ PCA } & \multicolumn{5}{|c}{ SPCA } \\
\cline { 2 - 9 } & $h=1$ & $h=3$ & $h=6$ & $h=12$ & $h=1$ & $h=3$ & $h=6$ & $h=12$ \\
\hline AR & 0.108 & 0.108 & 0.113 & 0.101 & 0.108 & 0.108 & 0.113 & 0.101 \\
\hline ARX & 1.210 & $1.647^{* *}$ & $1.561^{* *}$ & $1.554^{*}$ & 1.210 & $1.647^{* *}$ & $1.561^{* *}$ & $1.554^{*}$ \\
\hline CADL & 1.069 & 1.120 & 0.995 & 1.022 & 1.069 & 1.120 & 0.995 & 1.022 \\
\hline FAAR & 1.320 & 1.050 & $1.149^{*}$ & 1.198 & 1.346 & 0.989 & 1.019 & 1.195 \\
\hline PCR & 1.024 & 1.005 & 0.976 & 1.028 & 1.188 & $1.342^{* *}$ & 1.106 & 1.308 \\
\hline Bagg & 1.237 & 0.991 & 1.034 & 1.020 & 1.188 & $1.232^{*}$ & 1.029 & 1.113 \\
\hline Boost & 1.038 & 1.003 & 1.026 & 1.010 & 1.077 & $1.201^{* *}$ & 1.016 & 1.003 \\
\hline BMA1 & 1.077 & 1.016 & 1.034 & 1.029 & 1.104 & $1.401^{* *}$ & 0.999 & 1.055 \\
\hline BMA2 & 1.084 & 1.002 & 1.048 & 1.049 & 1.112 & $1.426^{* *}$ & 1.008 & 1.078 \\
\hline Ridge & 1.078 & 0.973 & 1.056 & 1.062 & 1.137 & $1.270^{*}$ & 1.028 & 1.069 \\
\hline LAR & 0.967 & 1.015 & 1.007 & 0.989 & 1.018 & $1.096^{* *}$ & 1.007 & 1.017 \\
\hline EN & 0.967 & 1.015 & 1.007 & 0.989 & 1.018 & $1.096^{* *}$ & 1.007 & 1.016 \\
\hline NNG & 0.993 & 0.989 & 1.025 & 0.983 & 1.003 & $1.054^{*}$ & 1.020 & 1.023 \\
\hline Mean & 0.939 & 0.958 & 1.001 & 0.970 & 0.988 & 1.048 & 0.979 & 0.964 \\
\hline
\end{tabular}

Notes: See notes to Table 3. 


\section{Results: Gross Capital Formation}

Tables 10 and 11 report the relative MSFEs of the forecasts for gross capital formation $(G C F)^{10)}$ over the previous month and over the same month in the previous year respectively. Similarly to in other cases, in the month-on-month forecast, the models estimated by SPCA work better than those for PCA. Surprisingly, FAAR, PCA and Bagg in SPCA perform much better than they do in any other cases. Those models track the high volatility of the rate of month-on-month growth of GCF in March-May 2009, July 2011 and July 2012 well, and these exceptions to the general results make huge differences in relative MSFEs in Table 10. As a result, those models under SPCA perform best among all models, and the dominance of SPCA over PCA in the month-on-month growth rates is thus confirmed again. In Table 11, PCR models under PCA have the lowest MSFE for every horizon and differ significantly from AR model except in a month ahead forecast. Although many hybrid models are significantly better than AR, FAAR and PCR, which do not shrink factors, also work well. It can also be interpreted that the estimated factors are sufficient for forecasting the target variables well, and that we may not need a more parsimonious model for the Korean macroeconomic data in order to improve the predictive accuracy.

10) Note that, given the data availability, the results are based on the recent five years' out-of-sample forecasting experiment. 
Table 10: MSFEs for Month-on-Month Growth in GCF

\begin{tabular}{c|c|c|c|c|c|c|c|c}
\multirow{2}{*}{ Method } & \multicolumn{9}{|c|}{ PCA } & \multicolumn{5}{c}{ SPCA } \\
\cline { 2 - 9 } & $h=1$ & $h=3$ & $h=6$ & $h=12$ & $h=1$ & $h=3$ & $h=6$ & $h=12$ \\
\hline AR & 0.523 & 0.602 & 0.645 & 0.471 & 0.523 & 0.602 & 0.645 & 0.471 \\
\hline ARX & 0.878 & 0.823 & 0.891 & 1.294 & 0.878 & 0.823 & 0.891 & 1.294 \\
\hline CADL & 0.953 & 0.987 & 0.984 & 0.985 & 0.953 & 0.987 & 0.984 & 0.985 \\
\hline FAAR & 0.857 & 0.949 & 0.882 & 0.959 & 0.410 & 0.276 & 0.138 & 0.223 \\
\hline PCR & 1.117 & 0.950 & $0.876^{*}$ & 1.013 & 0.521 & 0.460 & $0.286^{*}$ & 0.396 \\
\hline Bagg & 0.978 & 0.877 & 1.063 & 1.003 & 0.373 & 0.344 & 0.222 & 0.167 \\
\hline Boost & 0.945 & 1.019 & $0.936^{*}$ & 0.934 & 0.989 & 1.127 & 1.108 & 1.087 \\
\hline BMA1 & 0.943 & 1.035 & $0.923^{*}$ & 0.939 & 1.002 & 1.139 & 1.130 & 1.093 \\
\hline BMA2 & 0.927 & 0.999 & $0.912^{*}$ & 0.943 & 1.007 & 1.139 & 1.134 & 1.099 \\
\hline Ridge & 0.902 & 0.916 & $0.915^{*}$ & 0.943 & 0.371 & 0.323 & 0.190 & 0.235 \\
\hline LAR & 1.013 & 1.050 & $0.960^{*}$ & 0.969 & 0.996 & 1.155 & 1.093 & 1.080 \\
\hline EN & 1.013 & 1.049 & $0.960^{*}$ & 0.969 & 0.996 & 1.135 & 1.094 & 1.079 \\
\hline NNG & 1.005 & 1.016 & $0.953^{*}$ & 0.977 & 0.993 & 1.016 & 1.013 & 1.022 \\
\hline Mean & 0.895 & 0.927 & $0.899^{*}$ & 0.928 & 0.350 & 0.308 & 0.151 & 0.210 \\
\hline
\end{tabular}

Notes: See notes to Table 3.

Table 11: MSFEs for Year-on-Year Growth in GCF

\begin{tabular}{c|l|l|l|l|l|l|l|l}
\multirow{2}{*}{ Method } & \multicolumn{9}{|c|}{ PCA } & \multicolumn{5}{c}{ SPCA } \\
\cline { 2 - 9 } & $h=1$ & $h=3$ & $h=6$ & $h=12$ & $h=1$ & $h=3$ & $h=6$ & $h=12$ \\
\hline AR & 0.495 & 0.955 & 1.584 & 1.805 & 0.495 & 0.955 & 1.584 & 1.805 \\
\hline ARX & 1.105 & $0.699^{*}$ & 1.032 & 1.000 & 1.105 & $0.699^{*}$ & 1.032 & 1.000 \\
\hline CADL & 0.913 & $0.823^{*}$ & $0.805^{*}$ & 0.869 & 0.913 & $0.823^{*}$ & $0.805^{*}$ & 0.869 \\
\hline FAAR & 0.715 & $0.484^{*}$ & $0.314^{*}$ & $0.377^{* *}$ & 0.919 & 0.801 & $0.727^{*}$ & 0.769 \\
\hline PCR & 0.714 & $0.448^{*}$ & $0.307^{*}$ & $0.357^{* *}$ & $1.549^{*}$ & 1.208 & 1.125 & 0.917 \\
\hline Bagg & $3.572^{* *}$ & $1.958^{*}$ & 0.978 & $0.668^{* *}$ & 1.003 & 0.844 & 1.065 & $0.724^{* *}$ \\
\hline Boost & $0.878^{*}$ & $0.577^{*}$ & $0.412^{* *}$ & $0.387^{* *}$ & 0.955 & 0.878 & 1.100 & 1.000 \\
\hline BMA1 & $0.829^{*}$ & $0.546^{*}$ & $0.409^{*}$ & $0.389^{* *}$ & 0.981 & 0.869 & 1.160 & $1.301^{*}$ \\
\hline BMA2 & $0.828^{*}$ & $0.555^{*}$ & $0.414^{* *}$ & $0.392^{* *}$ & 0.981 & 0.876 & 1.161 & $1.285^{*}$ \\
\hline Ridge & $0.820^{* *}$ & $0.555^{*}$ & $0.370^{*}$ & $0.395^{* *}$ & 0.940 & 0.910 & 1.150 & 0.998 \\
\hline LAR & 0.970 & $0.871^{*}$ & $0.798^{*}$ & $0.848^{* *}$ & 0.984 & $0.929^{*}$ & 0.941 & 1.002 \\
\hline EN & 0.970 & $0.871^{*}$ & $0.798^{*}$ & $0.848^{* *}$ & 0.983 & $0.931^{*}$ & 0.942 & 1.003 \\
\hline NNG & $0.948^{*}$ & $0.956^{* *}$ & $0.962^{* *}$ & $0.978^{* *}$ & 0.958 & 0.940 & 0.997 & 0.981 \\
\hline Mean & $0.818^{* *}$ & $0.583^{* *}$ & $0.510^{* *}$ & $0.473^{* *}$ & $0.884^{*}$ & $0.815^{*}$ & 0.962 & $0.853^{* *}$ \\
\hline
\end{tabular}

Notes: See notes to Table 3. 


\section{Concluding Remarks}

We investigate the usefulness of factor augmented autoregressive models with various dimension reduction methods for Korean macroeconomic variables. We forecast five variables - consumer inflation, GDP growth, consumption, exports and gross capital formation - using data dimension reduction methods such as principal component analysis (PCA) and sparse principal component analysis (SPCA), combined with various shrinkage methods. First, we analyze the composition of Korean macroeconomic variables using SPCA. The main ingredients are interest rates, values of construction orders received, and employment variables. Notably, the weights of variables from the interest rates and the employment groups have been increasing, while those from the values of construction orders received has been decreasing.

The findings in the above forecasting experiment can be summarized as follows; In the one month ahead predictions, hybrid models outperform the benchmark models, including autoregression, for both month-on-month and year-on-year growth. However, we cannot pick one specific model which dominates others; As the forecast horizon lengthens, the forecasts for the year-on-year growth rate improve compared to those for month-on-month growth. And while no individual model can outperform the others for month-on-month growth (although the hybrids give better predictions than the benchmark), in the case of the year-on-year growth FAAR or PCR show the lowest MSFEs, especially for GDP and GCF, which becomes clearer with longer forecast horizons.

In most of the cases that we consider, the hybrid models give better predictions than the benchmark models, regardless of the factor estimation methods. But in comparing of the two methods, PCA gives more accurate predictions than SPCA under the same forecasting framework in our out-of-sample experiment. Our finding is thus contrary to general consensus, that more parsimonious model leads to a better forecast. This may be because a tuning parameter of SPCA, which controls the sparsity of loadings, may affect the quality of forecasts under SPCA. We leave more precise calibrations of tuning parameters to further research. A careful approach is required for applying factor methods in the sequel, in line with the 
following considerations. First, as we do not use real-time data, there must be a gap between the revised data and the first released. The model performance in longer forecast horizons may change if the model is estimated based on the first-released data. Second, we see that FAAR and PCR models work very well in many cases, but also that the mean of other models (Mean) works well universally. However, there also remain issues regarding model averaging, such as what models we should use and how we should combine them. We need to work further on these issues to ensure more accurate predictions. 


\section{References}

Aiolfi, M., C. Capistranand, and A. Timmermann (2010), "Forecast Combinations," Working Paper No. 2010-04, Banco de Mexico.

Ajevskis, V. and G. Davidsons (2008), "Dynamic Factor Models in Forecasting Latvias Gross Domestic Product," Latvijas Banka Working Paper.

Altavilla C. and P. De Grauwe (2010), "Forecasting and Combining Competing Models of Exchange Rate Determination," Applied Economics, Taylor and Francis Journals, vol. 42(27), pp. 3455-3480.

Angelini, E., M. Bańbura, and G. Rünstler (2008), "Estimating and Forecasting the Euro Area Monthly National Accounts from a Dynamic Factor Model," European Central Bank Working Paper No. 953.

Armah, N. A. and N. R. Swanson (2010), "Seeing inside the Black Box: Using Diffusion Index Methodology to Construct Factor Proxies in Large Scale Macroeconomic Time Series Environments," Econometric Reviews, vol. 29, pp. $476-510$.

Armah, N. A. and N. R. Swanson (2011). "Some Variables are More Worthy than Others: New Diffusion Index Evidence on the Monitoring of Key Economic Indicator," Applied Financial Economics, vol. 21, pp. 43-60.

Artis, M. J., A. Banerjee, and M. Marcellino (2002), "Factor Forecasts for the UK," CEPR Discussion Papers 3119.

Bai, J. and S. Ng (2002), "Determining the Number of Factors in Approximate Factor Models," Econometrica, vol. 70(1), pp. 191-221.

Bai, J. and S. Ng (2006), "Evaluating Latent and Observed Factors in Macroeconomics and Finance," Journal of Econometrics, vol. 131(1-2), pp. 507-537.

Bai, J. and S. Ng (2008), "Forecasting Economic Time Series using Targeted Predictors," Journal of Econometrics, vol. 146(2), pp. 304-317.

Bai, J. and S. Ng (2009), "Boosting Diffusion Indices," Journal of Applied Econometrics, vol. 24(4), pp. 607-629. 
Banerjee, A. and M. Marcellino (2008), "Factor-augmented Error Correction Models," CEPR Discussion Papers 6707.

Bańbura, M. and G. Rünstler (2011), "A Look into the Factor Blackbox: Publication Lags and the Role of Hard and Soft Data in Forecasting GDP," International Journal of Forecasting, vol. 27(2), pp. 333-346.

Bessec, M. (2012), "Short-term Forecasts of French GDP: A Dynamic Factor Model with Targeted Predictors,” Banque de France Working Paper No. 409.

Bjørnland, H. C., K. Gerdrup, A. S. Jore, C. Smith, and L. A. Thorsrud (2012), "Does Forecast Combination Improve Norges Bank Inflation Forecasts?," Oxford Bulletin of Economic and Statistics, vol. 74(2), pp. 163-179.

Boivin, J. and S. Ng (2005), "Understanding and Comparing Factor-based Forecasts," International Journal of Central Banking, vol. 1(3), pp. 117-152.

Boivin, J. and S. Ng (2006), "Are More Data Always Better for Factor Analysis?," Journal of Econometrics, vol. 132(1), pp. 169-194.

Breiman, L. (1995), "Better Subset Regression using the Nonnegative Garrote," Technometrics, vol. 37(4), pp. 373-384.

Breiman, L. (1996), "Bagging Predictors," Machine Learning, vol. 24(2), pp. 123-140.

Chen, C.-C. and H.-W. Lin (2011), "The Advantages of Dynamic Factor Models as Techniques for Forecasting: Evidence from Taiwanese Macroeconomic Data," International Journal of Economics and Finance, vol. 3(5), pp. 208-215.

Cheung, C. and F. Demers (2007), "Evaluating Forecasts from Factor Models for Canadian GDP Growth and Core Inflation," Bank of Canada Working Paper 2007-8.

Chow, H. K. and K. M. Choy (2008), "Forecasting Business Cycles in a Small Open Economy: A Dynamic Factor Model for Singapore,” Economic Growth Centre, Nanyang Technological University, Working Paper 2008/02.

Chow, G. C. and A.-1. Lin (1971), "Best Linear Unbiased Interpolation, Distribution, and Extrapolation of Time Series by Related Series," The Review of Economics and Statistics, vol. 53(4), pp. 372-375. 
Clark, Todd E. and Michael W. McCracken (2009), "Combining Forecasts from Nested Models," Oxford Bulletin of Economics and Statistics, vol. 71(3), pp. 303-329.

Clements, M. and D. Harvey (2009), "Forecast Combination and Encompassing," Palgrave Handbook of Econometrics: Volume 2 Applied Econometrics, Terence C. Mills and Kerry Patterson eds., Chapter 4, pp. 169-199.

Diebold, Francis X. (1998), "Elements of Forecasting," Cincinnati: South-Western College Publishing.

Diebold, F. X. and J. A. Lopez (1995), "Forecast Evaluation and Combination," Handbook of Statistics, G. S. Maddala and C.R. Rao eds.

Diebold, F. X. and R. S. Mariano (1995), "Comparing Predictive Accuracy," Journal of Business \& Economic Statistics, vol. 13(3), pp. 253-263.

Ding, A. A. and J. T. G. Hwang (1999), "Prediction Intervals, Factor Analysis Models, and High-dimensional Empirical Linear Prediction," Journal of the American Statistical Association, vol. 94(446), pp. 446-455.

Drought, S. and C. McDonald (2011), "Forecasting House Inflation: A Model Combination Approach," Reserve Bank of New Zealand Discussion Paper Series 2011/07.

Dufour, J.-M. and D. Stevanovic (2010), "Factor-augmented Varma Models: Identification, Estimation, Forecasting and Impulse Responses," Working paper, McGill University.

Efron, B., T. Hastie, L. Johnstone, and R. Tibshirani (2004), "Least Angle Regression," Annals of Statistics, vol. 32, pp. 407-499.

Eklund, J. and S. Karlsson (2007), "Forecast Combination and Model Averaging using Predictive Measures," Econometric Reviews, vol. 26(2-4), pp. 329-363.

Elliott, G. and A. Timmermann (2004), "Optimal Forecast Combination under Regime Switching," CEPR Discussion Paper, No. 4649.

Engel, C., N. C. Mark, and K. D. West (2012), "Factor Model Forecasts of Exchange Rates," NBER Working Paper No. 18382. 
Freund, Y. and R. E. Schapire (1997), "A Decision-theoretic Generalization of On-line Learning and an Application to Boosting," Journal of Computer and System Sciences, vol. 55(1), pp. 119-139.

Godbout, C. and M. J. Lombardi (2012), "Short-term Forecasting of the Japanese Economy using Factor Models," Bank of Canada Working Paper 2012-7.

Gosselin, M.-A. and G. Tkacz (2001), "Evaluating Factor Models: An Application to Forecasting Inflation in Canada," Bank of Canada Working Paper 2001-18.

Gupta, R. and A. Kabundi (2011), "A Large Factor Model for Forecasting Macroeconomic Variables in South Africa," International Journal of Forecasting, vol. 27(4), pp. 1076-1088.

Hendry D.F. and K. Hubrich (2010), “Combining Disaggregate Forecasts or Combining Disaggregate Information to Forecast an Aggregate," European Central Bank Working Paper Series No. 1155, European Central Bank.

Genre, V., G. Kenny, A. Meyler, and A. Timmermann (2013), "Combining Expert Forecasts: Can Anything Beat the Simple Average?," International Journal of Forecasting, vol. 29, pp. 108-121.

Hoerl, A. and R. Kennard (1970), "Ridge Regression: Biased Estimation for Nonorthogonal Problems," Technometrics, vol. 12, pp. 55-67.

Ibarra-Ramirez, R. (2010), "Forecasting Inflation in Mexico using Factor Models: Do Disaggregated CPI Data Improve Forecast Accuracy?," Banco de Mexico, Working Papers No. 2010-01.

Jolliffe, I., N. Trendafilov, and M. Uddin (2003), "A Modified Principal Component Technique Based on the Lasso," Journal of Computational and Graphical Statistics, vol. 12, pp. 531-547.

Kapetanios, G., V. Labhard, and S. Price (2007), "Forecast Combination and the Bank of England's Suite of Statistical Forecasting Models," Bank of England, Working Paper No. 323.

Kim, H. H. and N. R. Swanson (2013a), "Forecasting Financial and Macroeconomic Variables using Data Reduction Methods: New Empirical Evi- 
dence," Journal of Econometrics, forthcoming.

Kim, H. H. and N. R. Swanson (2013b), "Mining Big Data using Parsimonious Factor and Shrinkage Methods," Working paper, Rutgers University.

Kinsbay, T. (2007), "The Use of Encompassing Test for Forecast Combinations," Working Paper 07/264, International Monetary Fund.

Kunovac, D. (2007), "Factor Model Forecasting of Inflation in Croatia," Financial Theory and Practice, vol. 31(4), pp. 371-393.

Lee, J. S. (2004), "Identifying Business Cycle Turning Points in Korea with a New Index of Aggregate Economic Activity," Bank of Korea Economic Analysis, vol. 10(1).

Luciani, M. (2011), "Forecasting with Approximate Dynamic Factor Models: the Role of Non-pervasive Shocks," ECARES Working Paper 2011-022.

Marcucci, J. (2008), "Are Common Factors Useful in Forecasting International Stock Market Realized Variances?,” Bank of Italy Working Paper.

Matheson, T. D. (2006), "Factor Model Forecasts for New Zealand," MPRA Paper No. 807.

den Reijer, A. H. (2005), "Forecasting Dutch GDP using Large Scale Factor Models," De Nederlandsche Bank, DNB Working Paper No. 28.

Rogleva, P. (2011), "Short-term Forecasting of Bulgarian GDP using a Generalized Dynamic Factor Model,” Bulagarian National Bank, Discussion Paper 86/2011.

Schneider, M. and M. Spitzer (2004), "Forecasting Austrian GDP using the Generlized Dynamic Factor Model," Oesterreichische Nationalbank, Working Paper 89.

Schumacher, C. (2007), "Forecasting German GDP using Alternative Factor Models Based on Large Datasets," Journal of Forecasting, vol. 26, pp. 271-302.

Shen, H. and J. Z. Huang (2008), "Sparse Principal Component Analysis via Regularized Low Rank Matrix Approximation," Journal of Multivariate Analysis, vol. 99(6), pp. 1015-1034. 
Stakènas, J. (2012), "Generating Short-term Forecasts of the Lithuanian GDP using Factor Models,” Lietuvos Bankas Working Paper No. 13.

Stock, J. H. and M. W. Watson (2002), "Forecasting using Principal Components from a Large Number of Predictors," Journal of the American Statistical Association, vol. 97, pp. 1167-1179.

Stock, J. H. and M. W. Watson (2004), "Combination Forecasts of Output Growth in a Seven-country Data Set," Journal of Forecasting; vol. 23(6), pp. $405-430$.

Stock, J. H. and M. W. Watson (2005), "Implications of Dynamic Factor Models for VAR Analysis,” NBER Working Papers 11467.

Stock, J. H. and M. W. Watson (2006), "Forecasting with Many Predictors," In Elliott, G., C. Granger, and A. Timmermann eds., Handbook of Economic Forecasting, volume 1, chapter10, pp. 515-554. Elsevier.

Stock, J. H. and M. W. Watson (2012), "Generalized Shrinkage Methods for Forecasting using Many Predictors," Journal of Business and Economic Statistics, vol. 30(4), pp. 481-493.

Tibshirani, R. (1996), "Regression Shrinkage and Selection via the LASSO," Journal of the Royal Statistical Society Series B-Methodological, vol. 58 (1), pp. 267-288.

Timmermann, A. G. (2005), "Forecast Combination”, CEPR Discussion Paper No. 5361.

Yuan, M. and Y. Lin (2007), "On the Non-negative Garrotte Estimator," Journal of the Royal Statistical Society, vol. 69(2), pp. 143-161.

Zou, H. and T. Hastie (2005), "Regularization and Variable Selection via the Elastic Net," Journal Of The Royal Statistical Society Series B, vol. 67(2), pp. 301-320.

Zou, H., T. Hastie, and R. Tibshirani (2006), "Sparse Principal Component Analysis," Journal of Computational and Graphical Statistics, vol. 15(2), pp. 262-286. 


\section{Appendix: List of predictors}

\begin{tabular}{|c|c|c|c|}
\hline$\#$ & Class & Type & Variable \\
\hline 1 & \multirow{18}{*}{$\begin{array}{l}\text { Interest } \\
\text { Rates }\end{array}$} & \multirow{14}{*}{$\begin{array}{l}\text { Domestic } \\
\text { Interest } \\
\text { Rates }\end{array}$} & Uncollateralized Call Rates(Overnight) \\
\hline 2 & & & $\begin{array}{l}\text { Uncollateralized Call Rates(Overnight, Direct Interbank } \\
\text { Transactions) }\end{array}$ \\
\hline 3 & & & $\begin{array}{l}\text { Uncollateralized Call Rates(Overnight, Intermediated } \\
\text { Transactions) }\end{array}$ \\
\hline 4 & & & Yields on CD(91-day) \\
\hline 5 & & & Yields on CP(91-day) \\
\hline 6 & & & Yields of National Housing Bonds Type1(5-year) \\
\hline 7 & & & Yields of Treasury Bonds(1-year) \\
\hline 8 & & & Yields of Treasury Bonds(3-year) \\
\hline 9 & & & Yields of Treasury Bonds(5-year) \\
\hline 10 & & & Yields of Treasury Bonds(10-yer) \\
\hline 11 & & & Yields of Monetary Stab. Bonds(2-year) \\
\hline 12 & & & Yields of Financial Debentures(1-year) \\
\hline 13 & & & Yields of Financial Debentures(3-Year) \\
\hline 14 & & & Yields of Corporate Bonds : O.T.C (3-year, BBB-) \\
\hline 15 & & \multirow{4}{*}{$\begin{array}{l}\text { Major } \\
\text { International } \\
\text { Interest } \\
\text { Rates }\end{array}$} & C/D(90days)(USA) \\
\hline 16 & & & T/N(2years)(USA) \\
\hline 17 & & & T/N(5years)(USA) \\
\hline 18 & & & Govt.Bond(5years)(Japan) \\
\hline 19 & \multirow{17}{*}{$\begin{array}{l}\text { Imports and } \\
\text { Exports }\end{array}$} & \multirow{17}{*}{$\begin{array}{l}\text { Value } \\
\text { Indexes } \\
\text { of Imports }\end{array}$} & Total \\
\hline 20 & & & Consumer Goods \\
\hline 21 & & & Cereal \\
\hline 22 & & & Direct Consumer Goods \\
\hline 23 & & & Durable Consumer Goods \\
\hline 24 & & & Electric Machine for Domestic Purpose \\
\hline 25 & & & Nondurable Consumer Goods \\
\hline 26 & & & Crude Material \& Fuel \\
\hline 27 & & & Fuel \\
\hline 28 & & & Crude Oil \\
\hline 29 & & & Mineral \\
\hline 30 & & & Light-industrial Crude Material \\
\hline 31 & & & Textile Yarn \& Thread \\
\hline 32 & & & Chemicals \\
\hline 33 & & & Iron \& Steel Product \\
\hline 34 & & & Non Ferreous Metal \\
\hline 35 & & & Capital Goods \\
\hline
\end{tabular}




\begin{tabular}{|c|c|c|c|}
\hline$\#$ & Class & Type & Variable \\
\hline 36 & \multirow{30}{*}{$\begin{array}{l}\text { Imports and } \\
\text { Exports }\end{array}$} & \multirow{6}{*}{$\begin{array}{l}\text { Value } \\
\text { Indexes } \\
\text { of Imports }\end{array}$} & Machinery \& Precision equipment \\
\hline 37 & & & Precision Equipment \\
\hline 38 & & & Electric electronic Machine \\
\hline 39 & & & Information\&communication's Equipment \\
\hline 40 & & & Semi-conductor \\
\hline 41 & & & Excluding Crude Petrolum \\
\hline 42 & & \multirow{24}{*}{$\begin{array}{l}\text { Value } \\
\text { Indexes of } \\
\text { Exports }\end{array}$} & Unit Value Index of Export \\
\hline 43 & & & Foods and Direct Consumer Goods \\
\hline 44 & & & Fish \& Shellfish \\
\hline 45 & & & Crude Material \& Fuels \\
\hline 46 & & & Petroleum \& Petroleum Products \\
\hline 47 & & & Light-industry Products \\
\hline 48 & & & Textile Yarn \& Thread \\
\hline 49 & & & Woven \& Textile Fabrics \\
\hline 50 & & & Clothing \\
\hline 51 & & & Tyres \& Inner Tube \\
\hline 52 & & & Gold \\
\hline 53 & & & Paper \& Paperboard \\
\hline 54 & & & Heavy-industry Products \\
\hline 55 & & & Chemicals \\
\hline 56 & & & Iron \& Steel Product \\
\hline 57 & & & Machinery \& Precision Equipment \\
\hline 58 & & & Precision Equipment \\
\hline 59 & & & Electric electronic Machine \\
\hline 60 & & & Electric machine for Domestic Purpose \\
\hline 61 & & & Information \& Communication Equiment \\
\hline 62 & & & Semi-conductor \\
\hline 63 & & & Passenger Car \\
\hline 64 & & & Excl. Semicond. Inform \& Comm. Equip. \\
\hline 65 & & & to Hong Kong \\
\hline 66 & \multirow{8}{*}{ Price } & \multirow{8}{*}{$\begin{array}{l}\text { Production } \\
\text { Price Index }\end{array}$} & All \\
\hline 67 & & & Commodities \\
\hline 68 & & & Agricultural, Forest \& Marine Products \\
\hline 69 & & & Services \\
\hline 70 & & & Transportation \\
\hline 71 & & & Financial Services \\
\hline 72 & & & Leasing \& Renting \\
\hline 73 & & & Other Services \\
\hline
\end{tabular}




\begin{tabular}{|c|c|c|c|}
\hline$\#$ & Class & Type & Variable \\
\hline 74 & \multirow{13}{*}{ Price } & \multirow{7}{*}{$\begin{array}{l}\text { Consumer } \\
\text { Price Index }\end{array}$} & Total Item \\
\hline 75 & & & Food and Non-Alcoholic Beverages \\
\hline 76 & & & Housing, Water, Electricity, Gas and Other Fuels \\
\hline 77 & & & $\begin{array}{l}\text { Furnishings, household equipment and routine household } \\
\text { maintenance }\end{array}$ \\
\hline 78 & & & Recreation and culture \\
\hline 79 & & & Restaurants and hotels \\
\hline 80 & & & Miscellaneous goods and services \\
\hline 81 & & \multirow{6}{*}{$\begin{array}{l}\text { Housing } \\
\text { Purchase } \\
\text { Price Index }\end{array}$} & All Groups \\
\hline 82 & & & All Groups(Seoul) \\
\hline 83 & & & Detached Dwelling \\
\hline 84 & & & Row House \\
\hline 85 & & & Apartment \\
\hline 86 & & & Apartment(Seoul) \\
\hline 87 & \multirow{23}{*}{ Money } & \multirow{15}{*}{$\begin{array}{c}\text { Money \& } \\
\text { Banking } \\
\text { (Monetary } \\
\text { Aggregates, } \\
\text { Deposits, } \\
\text { Loans \& } \\
\text { Discounts } \\
\text { etc.) }\end{array}$} & Bank Notes and Coins in Circulation(End Of) \\
\hline 88 & & & Monetary Base(End Of) \\
\hline 89 & & & M1(Narrow Money, End Of) \\
\hline 90 & & & M1-MMF(End of) \\
\hline 91 & & & M2(Broad Money, End Of) \\
\hline 92 & & & Lf(End Of) \\
\hline 93 & & & L(End of) \\
\hline 94 & & & Seasonally Ajusted M1(End of) \\
\hline 95 & & & Seasonally Ajusted M2(End of) \\
\hline 96 & & & Seasonally Adjusted Lf(End Of) \\
\hline 97 & & & Seasonally Adjusted L(End of) \\
\hline 98 & & & Total Deposits of CBs \& SBs. (End Of) \\
\hline 99 & & & Time \& Savings Deposits of CBs \& SBs. (End Of) \\
\hline 100 & & & Loans of CBs \& SBs(End Of) \\
\hline 101 & & & Turnover Ratio of Demand Deposits, CBs \& SBs \\
\hline 102 & & \multirow{5}{*}{$\begin{array}{l}\text { Loans \& } \\
\text { Discounts By } \\
\quad \text { Fund }\end{array}$} & Total Loans(CBs \& SBs) \\
\hline 103 & & & Equipment \\
\hline 104 & & & Operation \\
\hline 105 & & & Loans With Banking Funds \\
\hline 106 & & & Loans With Govt Funds \\
\hline 107 & & \multirow{3}{*}{$\begin{array}{c}\text { Loans and } \\
\text { Discounts of } \\
\text { the Bank of } \\
\text { Korea }\end{array}$} & TOTAL \\
\hline 108 & & & AGGR.LOANS PROV (TOTAL) \\
\hline 109 & & & AGGR.LOANS PROV (LOCAL) \\
\hline
\end{tabular}




\begin{tabular}{|c|c|c|c|}
\hline$\#$ & Class & Type & Variable \\
\hline 110 & \multirow{11}{*}{$\begin{array}{l}\text { Exchange } \\
\text { Rates }\end{array}$} & \multirow{11}{*}{$\begin{array}{c}\text { Arbitraged } \\
\text { Rates of } \\
\text { Major } \\
\text { Currencies } \\
\text { Against Won, } \\
\text { Longer } \\
\text { Frequency }\end{array}$} & Won per Japan Yen(100Yen) \\
\hline 111 & & & Won per Euro \\
\hline 112 & & & Won per United Kingdom Pound Sterling \\
\hline 113 & & & Won per Canadian Dollar \\
\hline 114 & & & Won per Swiss Franc \\
\hline 115 & & & Won per Hongkong Dollar \\
\hline 116 & & & Won per Sweden Swdish Krona \\
\hline 117 & & & Won per Australian Dollar \\
\hline 118 & & & Won per Denmark Danish Krone \\
\hline 119 & & & Won per Norwagian Krone \\
\hline 120 & & & Won per Saudi Riyal \\
\hline 121 & \multirow{25}{*}{$\begin{array}{l}\text { Value of } \\
\text { Orders }\end{array}$} & \multirow{25}{*}{$\begin{array}{c}\text { Value of } \\
\text { Machinery } \\
\text { Orders } \\
\text { Received }\end{array}$} & Total Value Ordered \\
\hline 122 & & & Domestic Demand \\
\hline 123 & & & Government and Public \\
\hline 124 & & & Private Demand \\
\hline 125 & & & Manufacturing \\
\hline 126 & & & Non-Manufacturing \\
\hline 127 & & & Agencies \\
\hline 128 & & & Overseas Demand \\
\hline 129 & & & Engines \\
\hline 130 & & & Special Purpose Machinery \\
\hline 131 & & & Metal Cutting and Forming \\
\hline 132 & & & General Purpose Machinery \\
\hline 133 & & & Communication Equipment \\
\hline 134 & & & Electrical Machinery \\
\hline 135 & & & Motor Vehicles \\
\hline 136 & & & Precise Process Control Equipment \\
\hline 137 & & & Total Value Ordered(Excluding Vessels) \\
\hline 138 & & & Domestic Demand(Excluding Vessels) \\
\hline 139 & & & Government and Public(Excluding Vessels) \\
\hline 140 & & & Private Demand(Excluding Vessels) \\
\hline 141 & & & Overseas Demand(Excluding Vessels) \\
\hline 142 & & & $\begin{array}{l}\text { Total Value Ordered } \\
\text { (Excluding Vessels } \cdot \text { Internal conversion engine for vessels) }\end{array}$ \\
\hline 143 & & & $\begin{array}{l}\text { Domestic Demand } \\
\text { (Excluding Vessels · Internal conversion engine for vessels) }\end{array}$ \\
\hline 144 & & & $\begin{array}{l}\text { Government and Public } \\
\text { (Excluding Vessels · Internal conversion engine for vessels) }\end{array}$ \\
\hline 145 & & & $\begin{array}{l}\text { Private Demand } \\
\text { (Excluding Vessels } \cdot \text { Internal conversion engine for vessels) }\end{array}$ \\
\hline
\end{tabular}




\section{BOK Working Paper No.2013-26 (2013.12)}

\begin{tabular}{|c|c|c|c|}
\hline$\#$ & Class & Type & Variable \\
\hline 146 & \multirow{22}{*}{$\begin{array}{l}\text { Value of } \\
\text { Orders }\end{array}$} & & $\begin{array}{l}\text { Overseas Demand } \\
\text { (Excluding Vessels - Internal conversion engine for vessels) }\end{array}$ \\
\hline 147 & & \multirow{21}{*}{$\begin{array}{c}\text { Value of } \\
\text { Domestic } \\
\text { Construction } \\
\text { Orders } \\
\text { Received }\end{array}$} & Total Orders Received \\
\hline 148 & & & Public \\
\hline 149 & & & Central Government \\
\hline 150 & & & Local Government \\
\hline 151 & & & Public Corporation \\
\hline 152 & & & Other Public Body \\
\hline 153 & & & Private \\
\hline 154 & & & Manufacturing \\
\hline 155 & & & Non-Manufacturing \\
\hline 156 & & & Building \\
\hline 157 & & & Dwellings \\
\hline 158 & & & Offices and Stores \\
\hline 159 & & & Factory and Storage \\
\hline 160 & & & Public Offices \\
\hline 161 & & & Others \\
\hline 162 & & & Civil Engineering \\
\hline 163 & & & Roads and Bridges \\
\hline 164 & & & Water Supply and Sewerage \\
\hline 165 & & & Generation of Electricity \\
\hline 166 & & & Land Development \\
\hline 167 & & & Installation of Machinery \\
\hline 168 & \multirow{14}{*}{ Inventory } & \multirow{14}{*}{$\begin{array}{l}\text { Inventory } \\
\text { Index by } \\
\text { Industry }\end{array}$} & All Groups \\
\hline 169 & & & Mining \& Manufacturing \\
\hline 170 & & & Mining and quarrying \\
\hline 171 & & & Mining of Coal, Crude Petroleum and Natural Gas \\
\hline 172 & & & Mining of Non-metallic Minerals, Except Fuel \\
\hline 173 & & & Manufacturing \\
\hline 174 & & & Manufacture of Food Products \\
\hline 175 & & & Manufacture of Beverages \\
\hline 176 & & & Manufacture of Tobacco Products \\
\hline 177 & & & Manufacture of Textiles, Except Apparel \\
\hline 178 & & & $\begin{array}{l}\text { Manufacture of wearing apparel, Clothing Accessories and } \\
\text { Fur Articles }\end{array}$ \\
\hline 179 & & & $\begin{array}{l}\text { Tanning and Dressing of Leather, Manufacture of Luggage } \\
\text { and Footwear }\end{array}$ \\
\hline 180 & & & $\begin{array}{l}\text { Manufacture of Wood and of Products of Wood and Cork ; } \\
\text { Except Furniture }\end{array}$ \\
\hline 181 & & & Manufacture of Pulp, Paper and Paper Products \\
\hline
\end{tabular}




\begin{tabular}{|c|c|c|c|}
\hline \# & Class & Type & Variable \\
\hline 182 & \multirow{14}{*}{ Inventory } & \multirow{14}{*}{$\begin{array}{l}\text { Inventory } \\
\text { Index by } \\
\text { Industry }\end{array}$} & $\begin{array}{l}\text { Manufacture of Coke, hard-coal and lignite fuel briquettes } \\
\text { and Refine }\end{array}$ \\
\hline 183 & & & $\begin{array}{l}\text { Manufacture of chemicals and chemical products (except } \\
\text { pharmaceuticals }\end{array}$ \\
\hline 184 & & & Manufacture of Rubber and Plastic Products \\
\hline 185 & & & Manufacture of Other Non-metallic Mineral Products \\
\hline 186 & & & Manufacture of Basic Metal Products \\
\hline 187 & & & $\begin{array}{l}\text { Manufacture of Fabricated Metal Products, Except } \\
\text { Machinery and Furniture }\end{array}$ \\
\hline 188 & & & $\begin{array}{l}\text { Manufacture of Electronic Components, Computer, Radio, } \\
\text { Television and }\end{array}$ \\
\hline 189 & & & $\begin{array}{l}\text { Manufacture of Medical, Precision and Optical Instruments, } \\
\text { Watches and }\end{array}$ \\
\hline 190 & & & Manufacture of electrical equipment \\
\hline 191 & & & Manufacture of Other Machinery and Equipment \\
\hline 192 & & & Manufacture of Motor Vehicles, Trailers and Semitrailers \\
\hline 193 & & & Manufacture of Other Transport Equipment \\
\hline 194 & & & Manufacture of Furniture \\
\hline 195 & & & Other manufacturing \\
\hline 196 & \multirow{6}{*}{ Housing } & \multirow{6}{*}{$\begin{array}{l}\text { Number of } \\
\text { Unsold } \\
\text { Houses in } \\
\text { Lots }\end{array}$} & Whole Country \\
\hline 197 & & & Seoul \\
\hline 198 & & & Busan \\
\hline 199 & & & Daegu \\
\hline 200 & & & Incheon \\
\hline 201 & & & Gwangju \\
\hline 202 & \multirow{12}{*}{ Housing } & \multirow{12}{*}{$\begin{array}{l}\text { Number of } \\
\text { Unsold } \\
\text { Houses in } \\
\text { Lots }\end{array}$} & Daejeon \\
\hline 203 & & & Ulsan \\
\hline 204 & & & Gyeonggi-do \\
\hline 205 & & & Gangwon-do \\
\hline 206 & & & Chungcheongbuk-do \\
\hline 207 & & & Chungcheongnam-do \\
\hline 208 & & & Jeollabuk-do \\
\hline 209 & & & Jeollanam-do \\
\hline 210 & & & Gyeongsangbuk-do \\
\hline 211 & & & Gyeongsangnam-do \\
\hline 212 & & & Jeju-do \\
\hline 213 & & & (National Capital Region) \\
\hline 214 & \multirow{4}{*}{$\begin{array}{c}\text { Wholesale } \\
\text { and Retail } \\
\text { Sales }\end{array}$} & \multirow{4}{*}{$\begin{array}{l}\text { Wholesale } \\
\text { and Retail } \\
\text { Sales Index }\end{array}$} & All Groups \\
\hline 215 & & & Sale of Motor Vehicles and Parts \\
\hline 216 & & & Sale of Motor Vehicles \\
\hline 217 & & & SaleofMotorVehiclePartsand two-wheeled vehicle \\
\hline
\end{tabular}




\section{BOK Working Paper No.2013-26 (2013.12)}

\begin{tabular}{|c|c|c|c|}
\hline \# & Class & Type & Variable \\
\hline 218 & \multirow{13}{*}{$\begin{array}{c}\text { Wholesale } \\
\text { and Retail } \\
\text { Sales }\end{array}$} & \multirow{13}{*}{$\begin{array}{l}\text { Wholesale } \\
\text { and Retail } \\
\text { Sales Index }\end{array}$} & Wholesale Trade \\
\hline 219 & & & Brokerage of Inductrial Agricultural Raw Materials \\
\hline 220 & & & Wholesale of Food, Beverages and Tobaccos \\
\hline 221 & & & Wholesale of Household Goods \\
\hline 222 & & & Wholesale of Machinery Equipment and Supplies \\
\hline 223 & & & Wholesale of Construction Materials and Hardware \\
\hline 224 & & & Other Specialized Wholesale \\
\hline 225 & & & Retail Trade \\
\hline 226 & & & Retail Sale in Non-Specialized Stores \\
\hline 227 & & & $\begin{array}{l}\text { Retail Sale of Foods, Beverages and Tobacco in Specialized } \\
\text { Stores }\end{array}$ \\
\hline 228 & & & Retail Sale of Textiles, Clothing and Footwear Goods \\
\hline 229 & & & Retail Sale of Fuel \\
\hline 230 & & & Retail Sale not in Stores \\
\hline 231 & \multirow{24}{*}{ Manufacturing } & \multirow{18}{*}{$\begin{array}{l}\text { Manufacturing } \\
\text { Production } \\
\text { Index by } \\
\text { Special } \\
\text { Classification }\end{array}$} & All Items \\
\hline 232 & & & Capital Goods \\
\hline 233 & & & Manufacturing Equipment \\
\hline 234 & & & Electricity \\
\hline 235 & & & Communication \\
\hline 236 & & & Transportation Equipment \\
\hline 237 & & & Agriculture \\
\hline 238 & & & Construction \\
\hline 239 & & & Office \\
\hline 240 & & & Others \\
\hline 241 & & & Intermediate Goods \\
\hline 242 & & & Manufacturing \\
\hline 243 & & & Construction \\
\hline 244 & & & Fuel and Electricity \\
\hline 245 & & & Others \\
\hline 246 & & & Consumers' Goods \\
\hline 247 & & & Durable Consumers' Goods \\
\hline 248 & & & Non-Durable Consumers' Goods \\
\hline 249 & & \multirow{6}{*}{$\begin{array}{l}\text { Manufacturing } \\
\text { Operation } \\
\text { Ratio Index } \\
\text { Manufacturing } \\
\text { Operation } \\
\text { Ratio Index }\end{array}$} & Manufacture \\
\hline 250 & & & Food Products \\
\hline 251 & & & Beverages Products \\
\hline 252 & & & Tobacco Products \\
\hline 253 & & & Petroleum Products \\
\hline 254 & & & $\begin{array}{l}\text { Manufacture of wearing apparel, Accessories and Fur } \\
\text { Articles }\end{array}$ \\
\hline
\end{tabular}




\begin{tabular}{|c|c|c|c|}
\hline$\#$ & Class & Type & Variable \\
\hline 255 & \multirow{16}{*}{ Manufacturing } & \multirow{16}{*}{$\begin{array}{l}\text { Manufacturing } \\
\text { Operation } \\
\text { Ratio Index } \\
\text { Manufacturing } \\
\text { Operation } \\
\text { Ratio Index }\end{array}$} & Tanning and Dressing of Leather, Luggage and Footwear \\
\hline 256 & & & Manufacture of Wood and of Products of Wood and Cork \\
\hline 257 & & & Pulp, Paper and Paper Products \\
\hline 258 & & & $\begin{array}{l}\text { Coke, hard-coal and lignite fuel briquettes and Refined } \\
\text { Petroleum Products }\end{array}$ \\
\hline 259 & & & Chemicals and chemical products \\
\hline 260 & & & Rubber and Plastic Products \\
\hline 261 & & & Non-metallic Mineral Products \\
\hline 262 & & & Basic Metal Products \\
\hline 263 & & & Fabricated Metal Products \\
\hline 264 & & & $\begin{array}{l}\text { Electronic onents, Computer, Radio, Television and } \\
\text { Communication Equipment and Apparatuses }\end{array}$ \\
\hline 265 & & & Medical, Precision and Optical Instruments, Watches \\
\hline 266 & & & Electrical Equipment \\
\hline 267 & & & Other Machinery and Equipment \\
\hline 268 & & & Motor Vehicles, Trailers and Semitrailers \\
\hline 269 & & & Other Transport Equipment \\
\hline 270 & & & Other manufacturing \\
\hline 271 & \multirow{14}{*}{ Employment } & \multirow{6}{*}{ Unemployed } & Total \\
\hline 272 & & & Less than $3 \mathrm{mo}$. \\
\hline 273 & & & More than $3 \mathrm{mo}$. And Less than $6 \mathrm{mo}$. \\
\hline 274 & & & More than $6 \mathrm{mo}$. And Less than $12 \mathrm{mo}$. \\
\hline 275 & & & More than $6 \mathrm{mo}$. \\
\hline 276 & & & More than $12 \mathrm{mo}$. \\
\hline 277 & & \multirow{8}{*}{ Labor Force } & Pop.15 Years Old and Over \\
\hline 278 & & & Economically Active Pop. \\
\hline 279 & & & Employed Persons \\
\hline 280 & & & Unemployed Persons \\
\hline 281 & & & Not Economically Active Pop. \\
\hline 282 & & & Participation Rate \\
\hline 283 & & & Unemployment Rate \\
\hline 284 & & & Employment Rate \\
\hline 285 & \multirow{6}{*}{ Output } & \multirow{6}{*}{$\begin{array}{l}\text { Production } \\
\text { Index by } \\
\text { Industry }\end{array}$} & All Groups \\
\hline 286 & & & Mining and Manufacturing \\
\hline 287 & & & Mining \\
\hline 288 & & & Manufacturing \\
\hline 289 & & & Publishing activities \\
\hline 290 & & & Total index(Including Publishing activities) \\
\hline
\end{tabular}




\begin{tabular}{|c|c|c|c|}
\hline$\#$ & Class & Type & Variable \\
\hline 291 & \multirow{7}{*}{ Output } & \multirow{7}{*}{$\begin{array}{l}\text { Shipment } \\
\text { Index by } \\
\text { Industry } \\
\text { Shipment } \\
\text { Index by } \\
\text { Industry }\end{array}$} & All Groups \\
\hline 292 & & & Mining and Manufacturing \\
\hline 293 & & & Mining \\
\hline 294 & & & Manufacturing \\
\hline 295 & & & Electricity, gas \\
\hline 296 & & & Publishing activities \\
\hline 297 & & & Total index(Including Publishing activities) \\
\hline 298 & \multirow{6}{*}{ Misc } & & Total Equipment Index \\
\hline 299 & & & Leading Composite Index \\
\hline 300 & & & Coincident Composite Index \\
\hline 301 & & & Lagging Composite Index \\
\hline 302 & & & Cycle of Coincident Composite Index \\
\hline 303 & & & Cycle of Leading Composite Index \\
\hline 304 & \multirow{25}{*}{ Stocks } & \multirow{25}{*}{ KOSPI } & KOREA KOSPI 100 INDEX (KOSPI100) \\
\hline 305 & & & KOREA KOSPI 50 INDEX (KOSPI50) \\
\hline 306 & & & KOSPI 200 INDEX (KOSPI2) \\
\hline 307 & & & KOSPI BANKS INDEX (KOSPBANK) \\
\hline 308 & & & KOSPI CHEMICALS INDEX (KOSPCHEM) \\
\hline 309 & & & KOSPI COMMUNICATION INDEX (KOSPCOMM) \\
\hline 310 & & & KOSPI CONSTRUCTION INDEX (KOSPCONS) \\
\hline 311 & & & KOSPI DISTRIBUTION INDUS (KOSPWHOL) \\
\hline 312 & & & KOSPI ELECTRIC \& ELE EQU (KOSPELEC) \\
\hline 313 & & & KOSPI ELECTRICITY \& GAS (KOSPELGS) \\
\hline 314 & & & KOSPI FINANCE INDEX (KOSPFIN) \\
\hline 315 & & & KOSPI FOOD \& BEVERGE IX (KOSPFBEV) \\
\hline 316 & & & KOSPI INDEX (KOSPI) \\
\hline 317 & & & KOSPI INSURANCE INDEX (KOSPINSR) \\
\hline 318 & & & KOSPI Iron \& Metal Pr IX (KOSPBMET) \\
\hline 319 & & & KOSPI LARGE CAP INDEX (KOSPLMKC) \\
\hline 320 & & & KOSPI MACHINERY INDEX (KOSPMACH) \\
\hline 321 & & & KOSPI MANUFACT INDU INDX (KOSPMAN) \\
\hline 322 & & & KOSPI MEDIC SUPPLIES IDX (KOSPMED) \\
\hline 323 & & & KOSPI MEDICAL \& PREC MAC (KOSPMDEQ) \\
\hline 324 & & & KOSPI MID CAP INDEX (KOSPMMKC) \\
\hline 325 & & & KOSPI NONMETALLIC MINRL (KOSPNMET) \\
\hline 326 & & & KOSPI PAPER \& WOOD INDEX (KOSPPPRD) \\
\hline 327 & & & KOSPI SECURITIES INDEX (KOSPSEC) \\
\hline 328 & & & KOSPI SERVICES INDEX (KOSPSERV) \\
\hline
\end{tabular}




\begin{tabular}{|c|c|c|c|}
\hline$\#$ & Class & Type & Variable \\
\hline 329 & \multirow{12}{*}{ Stocks } & \multirow{4}{*}{ KOSPI } & KOSPI SMALL CAP INDEX (KOSPSMKC) \\
\hline 330 & & & KOSPI TEXTILE \& WEAR APP (KOSPTXAP) \\
\hline 331 & & & KOSPI TRANSPORT \& STRGE (KOSPTRAN) \\
\hline 332 & & & KOSPI TRANSPORT EQUIPMT (KOSPTREQ) \\
\hline 333 & & \multirow{8}{*}{ KOSDAQ } & KOSDAQ 100 INDEX (KOSD100) \\
\hline 334 & & & KOSDAQ CONSTRUCTION INDEX (KOSCNST) \\
\hline 335 & & & KOSDAQ DISTRIB SRVC INDEX (KOSDIST) \\
\hline 336 & & & KOSDAQ FINANCE INDEX (KOSFINC) \\
\hline 337 & & & KOSDAQ INDEX (KOSDAQ) \\
\hline 338 & & & KOSDAQ IT COMPOSITE INDEX (KOSITCP) \\
\hline 339 & & & KOSDAQ MANUFACTURING INDEX (KOSMANU) \\
\hline 340 & & & KOSDAQ OTHERS INDEX (KOSOTHR) \\
\hline
\end{tabular}




\section{$<$ Abstract in Korean $>$}

\section{김현학*}

본고는 대용량의 데이터로부터 유용한 정보를 추출하는 팩터 모형(factor model)이 국내 거시경제 변수들을 전망하는데 있어 유용한지 살펴보았다. 이를 위해 널리 알려진 주성분분석(PCA) 외에 조금 더 간소한 모형을 구축하기 위해 설명력이 큰 소수의 변수들로 구성된 주성분을 추출하는 Sparse 주성분분석 (Sparse PCA)에 Stock and Watson (2012)와 Kim and Swanson (2013a)에서 사 용한 축약(shrinkage) 방법을 결합하여 혼합 예측 모형을 구성하고 2003년부터 2012년까지 물가, GDP, 수출, 소비 그리고 총자본형성을 예측하여 보았다. 분석 결과 변수들의 전기대비 및 전년 동기대비 성장률 예측에서 혼합모형들이 자기 회귀모형에 비해 나은 예측력을 보이는 것으로 나타났다. 혼합모형의 예측력은 전년 동기대비 성장률의 경우, 그리고 예측 시계가 길어질수록 더 좋아지는 것 으로 분석되었다. 특히 큰 변동성을 보이는 경제 위기 시에 자기회귀모형에 비 해 혼합모형들은 각 변수들의 변곡점을 더 잘 예측하는 것으로 나타났다.

* 한국은행 경제연구원 거시경제연구실 전문연구원, khdouble@bok.or.kr 